\title{
„NOWY” GRÓDEK PÓŹNOŚREDNIOWIECZNY \\ W REJONIE JEZIOR BNIŃSKICH \\ (BŁAŻEJEWO, GM. KÓRNIK, WOJ. WIELKOPOLSKIE)
}

\author{
A "NEW" LATE MEDIEVAL STRONGHOLD \\ IN THE REGION OF THE BNIN LAKES \\ (BŁAŻEJEWO, KÓRNIK COMMUNE, WIELKOPOLSKA VOIVODESHIP)
}

\begin{abstract}
Jerzy Fogel
Instytut Prahistorii, Uniwersytet im. Adama Mickiewicza

ul. Św. Marcin 78, 61-809 Poznań, Poland

Jarostaw Jasiewicz

Instytut Badań Czwartorzędu i Geoekologii, Uniwersytet im. Adama Mickiewicza

ul. Fredry 10,61-701 Poznań, Poland

\section{Alina Losińska}

Instytut Archeologii i Etnologii PAN, Oddział Poznański

ul. Zwierzyniecka 20, 60-814 Poznań, Poland

\section{Andrzej Sikorski}

Instytut Prahistorii, Uniwersytet im. Adama Mickiewicza

ul. Św. Marcin 78, 61-809 Poznań, Poland

ABSTRACT. The document from 1422, published in Codex Diplomaticus Maioris Poloniae (volume VIII, 1989, No. 935), refers to a fortified mansion from Błażejewo at the Bnin Lake, located about $25 \mathrm{~km} \mathrm{SE}$ from Poznań. The article presents results of archaeological and geological search of this construction that was undertaken in the year 2000. It was further confronted with other written sources referring to medieval history of two Wielkopolska magnate's houses: Grzymala and Łodzia-Bniński. The article is an important contribution to the recognition of the late medieval fortified architecture in the Wielkopolska region.
\end{abstract}

\section{PRZEGLĄD ŹRÓDEL PISANYCH}

Od ponad 30 lat obserwujemy wyraźny wzrost zainteresowania miediewistów polskich problematyką późnośredniowiecznych elit społecznych, zwłaszcza decyzyjnych kręgów politycznych i urzędniczych. Badania te, jako swoją podstawową 
metodę wykorzystujące genealogię, skupiają się głównie nad składem, struktura i rolą czołowych grup rodzinno-krewniaczych oraz nad karierami wybitnych postaci z tych kręgów ${ }^{1}$, w mniejszym zaś stopniu zajmują się ich pozycją majątkową i posiadanymi włościami ziemskimi. Dla tych ostatnich zagadnień niestety w znikomym stopniu wykorzystuje się dane dostarczane przez archeologów i historyków architektury - o wznoszonych i użytkowanych przez nich siedzibach czy rezydencjach, które były - jak się wydaje - materialnym odwzorowaniem zamożności i prestiżu społecznego. Te późnośredniowieczne siedziby rycersko-szlacheckie, zwykle o charakterze obronnym, pozostają dotąd głównie w kręgu zainteresowań archeologii historycznej, rejestrującej i badającej zachowane do dziś ruiny murowanych zamków i liczniejsze w środkowym pasie ziem polskich pozostałości drewnianych dworów budowanych na „kopcach”, zwane umownie gródkami stoźkowatymi, jak i całkowicie zatarte w obecnym krajobrazie ich ślady ${ }^{2}$. W źródłach pisanych ówcze-

' Rozległą problematykę badań genealogicznych, wznowionych w końcu lat $60 . \mathrm{XX}$ w. przez mediewistów polskich, obrazują liczne publikacje, m.in. Spoleczeństwo Polski średniowiecznej (t. I-VIII, Warszawa 1981-1999) i 6 tomów serii Genealogia - ... (Toruń 1982-1999), przedstawiających materiały z sympozjów organizowanych od 1980 r. przez ośrodek toruński. Warto też wymienić przykładowo kilka obszernych studiów: J. Bieniak, Wielkopolska, Kujawy, ziemia łęczycka i sieradzka wobec problemu zjednoczenia państwowego w latach 1300-1306, Toruń 1969; J. Pakulski, Ród Zarembów w Wielkopolsce w XIII i początkach XIV wieku, Bydgoszcz 1975; tenże, Nałęcze wielkopolscy w średniowieczu. Genealogia, uposażenie i rola polityczna w XII-XIV w., Warszawa 1982; A. Szweda, Ród Grzymatów w Wielkopolsce, Toruń 2001; M. Cetwiński, Rycerstwo ślqskie do końca XII w., cz. 1, Pochodzenie gospodarka - polityka, Wrocław 1980; cz. 2. Biogramy i rodowody, Wrocław 1982; T. Jurek, Obce rycerstwo na Ślqsku do połowy XIV wieku, Poznań 1996; A. Szymczakowa, Szlachta sieradzka w XV wieku. Magnifici et generosi, Łódź 1998. Dla genealogii Wielkopolski podstawowe znaczenie mają jednak nadal liczne monografie, m.in. kilkunastu rodów rycerskich, pióra ks. Stanisława Kozierowskiego (wydane w latach 1913-1933 w serii Studia nad pierwotnym rozsiedleniem rycerstwa wielkopolskiego...) i jego wielotomowe opracowania wydane w seriach: Badania nazw topograficznych... i Pienwotne osiedlenie... oraz cytowana wielokrotnie niżej praca Szematyzm historyczny ustrojow parafialnych dzisiejszej archidiecezji poznańskiej (Poznań 1935), a także Szematyzm historyczny ustrojów parafialnych dzisiejszej archidiecezji gnieźnieńskiej (Poznań 1934).

${ }^{2}$ Wiele stanowisk zostało całkowicie zniszczonych, a o ich istnieniu dowiadujemy się ze źródeł pisanych. Istnieje też pewna liczba obiektów dotąd nie zlokalizowanych w terenie, choć odnotowanych w zapiskach - te czekają na swoich odkrywców.

Z licznych publikacji na temat małych założeń mieszkalno-obronnych w Polsce późnośredniowiecznej wymienić należy (wyłączając pionierskie opracowania J. Kamińskiej, jak i dość bogatą literaturę „kastellologiczną”) książki pióra L. Kajzera: Studia nad świeckim budownictwem obronnym województwa tęczyckiego w XII-XVII wieku, Łódź 1980; Wstęp do badań archeologiczno-architektonicznych, Łódź 1984; Zamki i społeczeństwo. Przemiany architektury $i$ budownictwa obronnego w Polsce X-XVIII wieku, Łódź 1993; Wstęp do archeologii historycznej w Polsce, Łódź 1996; tegoż i J. Augustyniaka Wstęp do studiów nad świeckim budownictwem obronnym sieradzkiego w XIII-XVIII XXVIII wieku, Łódź 1986. Ukazały się też obszerne publikacje wyników badań archeologicznych późnośredniowiecznych obiektów obronnych z niektórych regionów Polski, jak np. Plemięta - średniowieczny gródek w ziemi chełmińskiej (red. A. Nadolski), Warszawa - Poznań - Toruń 1985; Średniowieczne siedziby rycerskie w Ziemi Chetmińskiej na tle badań podobnych obiektów na ziemiach polskich (red. A. Kola), 
sne obiekty mieszkalno-obronne określane są różnymi terminami łacińskimi: arx, castrum, castellum, fortalicium, curia militaris, curia muratum itp., pozwalającymi domyślać się dużej różnorodności form i funkcji tych założeń ${ }^{3}$.

Wprawdzie wstępna inwentaryzacja terenowa osiagnęła już znaczny stopień kompletności, m.in. dzięki przeprowadzanej akcji Archeologicznego Zdjęcia Polski, lista tych obiektów na obszarze XIV-XV-wiecznej Wielkopolski ciągle jest uzupełniana poprzez kwerendę w źródłach pisanych ${ }^{4}$. Takim całkowicie zniszczonym, a ostatnio „nowo odkrytym” dla archeologów obiektem jest castrum w Błażejewie koło Bnina, ,ujawnione” w trakcie przeglądania opublikowanego w 1999 r. indeksu do tomów VII-XI Kodeksu Dyplomatycznego Wielkopolski (zob. KDW, t. XI, s. 337; indeks opracowali: A. Gąsiorowski, T. Jurek i I. Skierska). Wzmianka o nim zawarta jest w dokumencie nr 935 z datą 9 marca 1422 r. (zob. KDW, t. VIII, 1989, s. 216217; kopia dokumentu w WAP Poznań - Pyzdry z. 11, k: 168v.-169. Wpis 11 maja 1451 r.), będącym potwierdzeniem przez starostę generalnego Wielkopolski - Sędziwoja z Ostroroga, podziału dóbr, którego dokonał Jan z Młynów ze swoją siostrą stryjeczną Małgorzatą żoną Andrzeja Błażejewskiego. Podaje on niezmiernie interesujące i dokładne dane dotyczące wznoszenia lub naprawy (rozbudowy?), zapewne przez wymienionego Andrzeja, budowli warownej w Błażejewie. Z tego względu wart jest powtórnej publikacji wraz z przekładem na język polski, dokonanym przez prof. dra hab. Kazimierza Limana z Instytutu Filologii Klasycznej UAM w Poznaniu.

In nomine Domini amen. Ad perpetuam rei memoriam. Nos Sandiwogius de Ostrorog palatinus Poznaniensis et capitaneus Maioris Polonie generalis significamus tenore presencium, quibus expedit universis, quomodo ad nostram et aliorum eiusdem terre nobilium veniens presenciam nobilis Johannes de Mlyny, non compulsus nec coactus neque aliquo errore devio seductus, sed sanus mente et corpore existens, usus amicorum consilio, spontanea voluntate et matura deliberacione prehabita, in omnibus nemoribus vulgaritet $l$ a $\mathrm{n} \mathrm{ze} \mathrm{ch}$ in silva alias

Torun 1987; A. Kola, Grody ziemi chełmińskiej w późnym średniowieczu, Toruń 1991; S. Kołodziejski, Sredniowieczne rezydencje obronne możnowtadztwa na terenie województwa krakowskiego, Kraków 1994; J. Tomala, Budownictwo obronne powiatu kaliskiego w XIV-XVIII wieku, Poznań 1995; R. Grygiel, T. Jurek, Doliwowie z Nowego Miasta nad Warta, Dębna i Biechowa. Dzieje rezydencji i ich wtaścicieli, Łódź 1996; ci sami, Zduny. Późnośredniowieczne i nowożytne rezydencje wtaścicieli miasta, Łódź 1999; oraz kilka monografii w serii Budownictwo obronno-rezydencjonalne Kujaw i Ziemi Dobrzyńskiej (cz. I-IV, Łódź 1990-1995).

${ }^{3}$ Zob. np. Marciniak 1991.

${ }^{4}$ Zob. kartoteka grodzisk w archiwum Pracowni Wczesnośredniowiecznej Instytutu Archeologii i Etnologii PAN, Oddział w Poznaniu (tam też niepublikowane w tomach I-VI Studiów i materiatów do osadnictwa Wielkopolski wczesnohistorycznej [SiM] wyniki późniejszych badań weryfikacyjnych prowadzonych na obszarze Wielkopolski od połowy lat 70. XX w.). Późnośredniowieczne obiekty obronne z d. woj. poznańskiego ujęte zostały też w: Kirschke, Prinke 1995. Grodzisko w Błażejewie nie figurowało dotąd nawet na liście obiektów domniemanych, a w SiM, t. I, 1950, s. 60-61, pod miejscowością Błażejewo, d. pow. Śrem podano tylko 2 stanowiska wczesnośredniowieczne nad Jeziorem Bnińskim, ujawnione w trakcie powierzchniowych badań w okresie międzywojennym. Wyniki powojennych penetracji powierzchniowych prezentuja Dzieduszyccy (1985). 
z a pow yednem lesz y e ac aliis silvis et borris, quecumque sunt in parte eiusdem Johannis in et super hereditatibus suis Czman et Ranka, quelibet robora quecumque ibidem haberi et ${ }^{a}[k .169]$ inveniri poterint pro construendis omnibus edificiis castri et ante castrum opportunis in Blosschegewo, videlicet domus, turrim plutheorum alias b la $\mathrm{n} \mathrm{k} \mathrm{y,} \mathrm{fossa} \mathrm{pontis}$ et pro quibusvis aliis edificiis ibidem in castro et ante castrum necessariis, nullis penitus exclusis, eciam in eisdem nemoribus silva inhibita et aliis silvis et bonis suis omnibus in hereditatibus predictis Czman et Ranka pro ignis, indigencia, quociens opportunum fuerit, ad castrum in Bloszyegowo etc. ligna dicta grab, pineta alias $\mathrm{ch}$ o y $\mathrm{n}$ y $\mathrm{n}$ y et rubetum pro molendinis domini Andree Blosschegewsky, eciam ad rotitracturas vulgariter $\mathrm{k} \mathrm{u} \mathrm{walom,tam}$ magnis, quam parwis, quocienscumque necessitas affuerit, strennuo domino Andree de Blosschegewo et Margarethe consorti sue legittime necnon pueris ac eorum legittimis successoribus scindendi racione realis divisionis cum ipsa domina Margareta, sorore sua parrueli uterina, dedit, deputavit, assignavit, legavit, ascripsit et coram nobis more solito racionabiliter imperpetuum resignavit et apropriavit de sua speciali voluntate. Harum quibus sigillum nostrum presentibus est appensum testimonio literarum. Actum et datum Poznanie feria secunda post dominicam Reminiscere anno Domini millesimo quadringentesimo vicesimo secundo, presentibus nobilibus: Derslao de Babyno, Johanne de Comornyky, Alberto de Splawye, Andrea de Gnoyno, Michaele Lunak et Nicolao de Lusszowo heredibus et aliis quampluribus fidedignis testibus ad premissa rogatis.

W imię Pańskie Amen. Na wieczną rzeczy pamiątkę. My Sędziwoj z Ostroroga, wojewoda poznański i starosta generalny Wielkopolski, oznajmiamy na podstawie przedłożonego pisma, wszystkim, którym jest to potrzebne, jakim to sposobem do naszej $\mathrm{i}$ innych tejże ziemi szlachciców dotarła świadomość, że szlachcic Jan z Młynów niczym nie przymuszony, ani nie zniewolony przymusem, ani nie zwiedziony jakimś przewrotnym blędem, lecz zdrowym na umyśle $i$ ciele będąc, po zasięgnięciu rady przyjaciół, z własnej woli i po poddaniu się dojrzałemu namysłowi [postanawia, że] we wszystkich mniejszych lasach (nemoribus), pospolicie zwanych landzech $w$ lesie inaczej zapowyednem leszye oraz $w$ innych lasach $\mathrm{i}$ borach, jakiegokolwiek drzewa, które znajdują się w dziedzinie tegoż Jana, w jego posiadłościach Czmoń i Rąka oraz poza nimi, wszelkie i jakiekolwiek [drzewa] będzie można tamże pozyskać i napotkać dla wzniesienia wszelkich odpowiednich budowli w miejscu obronnym (castri) i przed miejscem warownym w Błażejewie, mianowicie domów, wieży z daszkami inaczej b l a n k a mi, rowu [z?] drogą dylowana (pons) i dla wzniesienia jakichkolwiek innych budynków potrzebnych w miejscu warownym (castro) i przed nim (ante castrum), absolutnie żadnych nie wyłączając. Również z tychże mniejszych lasów [gajów?] wykluczając las i z innych lasów i wszelkich dóbr swoich we wspomnianych posiadłościach Czmoń i Rąka, ilekroć z braku [opału?] na ogień, będzie konieczne, na warowne miejsce (castrum) w Błażejewie itd. Wspomniane drewno - grab, las iglasty inaczej choynyny i krzewiny dla potrzeb młynów pana Andrzeja Błażejewskiego, również na potrzeby drogi potocznie zwanej $\mathrm{k} \mathrm{u}$ wa lo m, tak wielkich jak i małych, przedsiębiorczemu panu Andrzejowi Błażejewskiemu i jego prawowitej małżonce Małgorzacie, jak również dzieciom (pueris) i ich prawowitym następcom na podstawie faktycznego podziału wraz z tą samą panią Małgorzatą, rodzoną siostrą swoją stryjeczną dał, przekazał, przysądzil, zapisał, przyznał w testamencie i wobec nas, przyjętym zwyczajem w rozumny sposób na zawsze przeniesienia własności dokonał i na własność szczególną wolą swoją oddał. Pieczęć naszą w ich obecności przywieszono na świadectwo tego dokumentu. Zdziałane i dane w Poznaniu, w poniedziałek po niedzieli Reminiscere Roku Pańskiego 1422 w obecności szlachciców Dziersława z Babina, Jana z Komornik, Alberta ze Spławia, Andrzeja z Gnojna, Michała Lunaka i Mikołaja z Lusowa dziedziców i innych licznych godnych zaufania świadków na to co spisano wyżej zaproszonych. 
Omawiany dokument z 1422 r. jest swoistego rodzaju zapisem majątkowym sporządzonym przez Grzymalitę Jana z Młynów kilka lat przed śmiercią ( $†$ po 1424 r.). Powstał on zapewne $z$ inicjatywy Małgorzaty i jej męża, pragnących uprawomocnić uprawnienia należne Małgorzacie z racji dziedzicznych działów majątkowych. Spisano go w Poznaniu w obecności - jak zaznaczono w tekście - „zaproszonych licznych godnych zaufania" świadków, spośród których pięć osób wymieniono imiennie, w tym Jana z Komornik (koło Tulec), późniejszego burgrabiego poznańskiego (w latach 1434-1436, 1440), a następnie wicewojewodę poznańskiego $(1442 \text { r. })^{5}$. Nie odnotowano obecności znaczniejszych przedstawicieli rodu Grzymałów. Akt ten potwierdził najwyższy rangą urzędnik wielkopolski - starosta generalny Sędziwoj z Ostroroga.

Interesujące są informacje o powiązaniach rodzinnych i sytuacji majątkowej osób będących podmiotami spisanej w $1422 \mathrm{r}$. umowy, a więc Grzymality Jana z Młynów (Johannes de Mlyny) i jego siostry stryjecznej Małgorzaty, jak i jej męża Andrzeja (Andreas de Blosschegewo, Andreas Blosschegewsky). W świetle dostępnych zapisów źródłowych Grzymałowie Błażejewscy w końcu XIV i w pierwszych dziesięcioleciach XV wieku byli posiadaczami - a co najmniej współdziedzicami - następujących wsi: Błażejewo (,Błoźejewo”), Czmoń („Cman”, „Czman”), Czołowo, Młyny (,Mlyny”) i „Ranka” (Rąka, Ręka). Posiadłości te leżały na południowy zachód od Bnina - na obszarze między zachodnim brzegiem Jeziora Bnińskiego a południkowym odcinkiem biegu Warty (na północy po jej zakole na wysokości obecnej wsi Radzewice). Nie istniejąca obecnie wieś Młyny identyfikowana jest - może niewłaściwie z małą osadą Trzykolne Młyny, leżącą teraz na zachodnim brzegu Warty. Prawdopodobnie na wschód od Warty, w sąsiedztwie Czmonia i Orkowa, leżała zaginiona osada „Ranka”, wymieniona obok Czmonia w dokumencie z 1422 r. jako posiadłość Jana z Młynów 6 .

Małgorzata z rodu Grzymałów, żona Andrzeja - jak wynika z tablic genealogicznych Grzymałów wielkopolskich opracowanych przez Adama Szwedę $e^{7}$ była jedynaczką, córką Jarosława z Czołowa ( $†$ po 1405 r.), zaś jej brat stryjeczny Jan

${ }^{5}$ Gasiorowski 1968, s. 151, nr C 923 i 926, s. 153, nr 954.

${ }^{6} \mathrm{Na}$ temat osady „Ranka” zob. Kozierowski 1916b, s. 130, 131. Dawna wieś Młyny (należąca do parafii Radzewo; zob. Kozierowski 1916a, s. 473) wzmiankowana w 1359 r. (KDW, t. III, nr 2051) jako wlasność Bogusława Młyńskiego, a w 1417, 1419 i 1443 r. jako posiadłość Jarosława „de Mlini”, mogła leżeć też bliżej Kórnika.

Warto tu dodać, że zachodni skraj posiadłości tej gałęzi Grzymałów obejmował obecnie słabo zaludnione oraz silnie zalesione i nieużytkowane rolniczo tereny, przecięte uregulowanym w czasach nowożytnych korytem Warty. Charakterystyczną cechą obecnego krajobrazu są liczne starorzecza, zachowane do dziś wzdłuż biegu Warty od Rogalinka po Śrem. W średniowieczu te rozlewiska Warty mogły być gospodarczo intensywnie wykorzystywane, m.in. jako miejsca odławiania ryb oraz pod budowę dochodowych młynów wodnych.

${ }^{7}$ Szweda 2001, tabl. IX, X (praca ta ukazała się już po złożeniu niniejszego artykułu do druku). 
z Młynów może być tożsamy z jedynym dotąd znanym w tym pokoleniu Janem, określonym przez A. Szwedę jako Jan z Czmania ( $\dagger$ po 1424 r.). Według cytowanego autora tenże Jan był synem Jana z Błażejewa ( $\dagger$ 1402/1404 r., ożenionego ze Śmichną z Kobylina h. Łodzia), najmłodszego z czterech synów Jarosława z Błażejewa († po 1377 r.), których dziadem był sędzia poznański (1339 r.), pieczętujący się herbem Grzymala Mikołaj z Błażejewa $(\dagger 1362 / 1363)^{8}$. Starsi bracia Jana z Błażejewa to: Jarosław z Czołowa - ojciec Małgorzaty, Maciej z Młynów († 1393/1397, żonaty z Małgorzatą, córką Wojsława Gryżyńskiego h. Borek; pozostawił córkę wydaną za Bodzantę z Chłapowa h. Dryja) oraz Mikołaj piszący się z Czmania, Błażejewa i Młynów († po 1404 r.) $)^{9}$. Znana jest też jedyna siostra owych czterech braci (synów Jarosława z Błażejewa) - Siechna († po 1404 r.), żona Wojciecha Skóra z Gaju h. Awdaniec, występującego w 1374 r. z godnością kasztelana radzimskiego. Podane wyżej koligacje rodzinne Małgorzaty wskazują na niepoślednią pozycję społeczną tej gałęzi Grzymałów.

Mniej danych udało się zebrać na temat Andrzeja Błażejewskiego - męża Małgorzaty z rodu Grzymałów, zapewne jedynej córki Jarosława z Czołowa. Jej mąż został określony przez A. Szwedę jako Andrzej z Dębca h. Łodzia. Bardzo prawdopodobna jest identyfikacja Andrzeja Błażejewskiego, pieczętującego się w 1432 r. h. Łodzia, z Andrzejem z Dębca h. Łodzia, a wówczas jego przodków i krewnych należałoby szukać wśród Łodziców Bnińskich ${ }^{10}$. Mógłby on być tożsamy z wymienionym przez S. Kozierowskiego „Łodzicem Andrzejem Błażejewskim a. Górskim z Tulec, Szczepankowa, Młyn i Radzewa" "1 . Mamy też informacje, że zapewne ten Andrzej (Andreas de Bloszejewo) w 1417 r. zakupił trzecią część wsi Konarskie (na zachód od Bnina), a przy działach rodzinnych Grzymałów w 1420 r. jemu i jego

${ }^{8}$ Mikołaj z Błażejewa h. Grzymała (sędzia poznański w latach 1339-1362; zob. Urzędnicy 1985, s. 151, nr 450) znany z dokumentów: KDW, t. II, nr 1221 z 1343 r. i nr 1263 z 1347 r. oraz KDW, t. III, nr 1327 z 1355 r. i nr 2051 z 1359 r. Jego syn - Jarosław z Błażejewa pod Bninem (posiadał część jeziora - toń przy końcu jeziora zwanego błażejewskim - zob. KDW, t. III, nr 1597 z 1368 r. oraz potwierdzenie w 1377 r. własności tej części jeziora w KDW, t. III, nr 1740) został przez S. Kozierowskiego zaliczony (nie wiadomo na jakiej podstawie) do rodu Doliwów (Kozierowski 1935, s. 22, przy czym powołuje się tu na wyżej wymieniony dokument z $1368 \mathrm{r}$. - KDW, t. III, nr 1597, mówiący o nabyciu zakupie(?) przez niego części jeziora - toni od Piotra Suczki, dziedzica Osłonina).

${ }^{9}$ Potomkami Mikołaja byli według A. Szwedy (2001, tabl. X): Jarosław z Młynów i Czmania (Czmonia), występujący w 1443 r. jako włodarz pszczewski ( $\dagger$ 1452/1456 r.), Bogusław z Młynów kanonik poznański, potem pleban wschowski ( $†$ po 1440 r.) oraz Janusz z Młynów ( $†$ 1446? r., pozostawiając syna i 2 córki). Zapewne do następnego pokolenia należy Jan z Młynów - stolnik kaliski w latach 1471-1476, podsędek kaliski w latach 1474-1476 (zob. Urzędnicy 1985, s. 120, nr 170, s. 125, nr 221).

${ }^{10}$ Dębiec (,Dembecz”) należał do Eodziców już w 1294 r. (KDW, t. II, nr 718) - wieś Mirosława Przedpełkowica. Zob. też Kozierowski 1916a, s. 127. O. Halecki $(1912$, s. 82) podaje, że występujący jako świadek na dokumentach Mikołaja z Górki (KDW, t. V, nr 432, 501) Andrzej z Błażejewa pieczętował się w 1432 r. herbem Łodzia. Dalsze dane o Andrzeju Błażejewskim podaje A. Szweda (2001, s. 155).

${ }^{11}$ Kozierowski 1935, s. 22. 
żonie przypadła trzecia część wsi Młyny i trzecia część wsi Radzewo ${ }^{12}$. Wypisy źródłowe, zgromadzone w kartotece Pracowni Słownika Historyczno-Geograficznego Wielkopolski Instytutu Historii PAN w Poznaniu' ${ }^{13}$, pozwalają wnosić, że w latach 20. XV w. Andrzej i Małgorzata Błażejewscy posiadali dość duże włości ziemskie, w tym też Dębiec (? Dębicz w parafii Bnin), będący pewnie wcześniejszą posiadłością Andrzeja, a także trudne do bliższego określenia wiano Małgorzaty i dobra uzyskane drogą działów lub zamiany dóbr wewnątrz rodu Grzymałów. W ich rękach w 1422 r. było już Błażejewo, z którego jeszcze w latach 1404-1405 pisali się Grzymalici - stryjowie Małgorzaty, a co najmniej od 1417 r. występuje jako nazwisko odmiejscowe Łodzica Andrzeja - męża Małgorzaty, a następnie ich synów Jana, Mikołaja i Wyszoty, znanych z dokumentu z 1440 r. (KDW, t. X, 1993, nr 1504). Sprawą otwartą pozostaje jednak bliższe ustalenie rodowodu tegoż Andrzeja, wywodzącego się - jak się wydaje - z bliżej dotąd nie rozpoznanych rozgałęzień Łodziców Bnińskich ${ }^{14}$.

Dalszych poszukiwań i studiów źródłowych wymagają też dzieje Błażejewskich i ich siedziby w 2. połowie XV w. Dotąd udało się natrafić na dwie kolejne wzmianki z 1446 r., mówiące o castrum - zamku w Błażejewie. Pierwsza dotyczy działów między synami Andrzeja - Janem, Mikołajem i Wyszotą. Wyszota występujący jako dziedzic w Starkowcu (pod Środa, w historycznym pow. pyzdrskim) przekazuje dziedziny (lub części osad) Błażejewo, Radzewo, Konarskie, Młyny i folwark zw. Thomasky oraz „wyrąb należący ad castrum in Bloszewowo” braciom rodzonym Janowi i Mikołajowi, w zamian oni przekazują Wyszocie wsie dziedziczne Starkowiec, Łagiewniki, Rzemachowo i Ochla (w pow. pyzdrskim), Mikołaj zaś oddaje całą wieś „Bloszeyewo z wyrębem w dziedzinach Czmań i Ranka należącym zdawna do zamku w Bl. w działach Janowi de Bl. bratu swemu rodzonemu". W tym samym roku 1446 starosta wielkopolski oznajmil, że Jan (Johannes olim Blozeyewsky) wieś Błażejewo z uprawnieniami należnymi z Czmonia i Ranki ,ad fortalicium Blozeyewo ... sprzedał nobilibus Petro, Alberto, Andree, Jeronimo et Benedicto de Campa fratribus" ${ }^{\prime 5}$. O. Halecki wysunął przypuszczenie, że w XV w. (po 1446 r.)

${ }^{12}$ Wielkopolskie roty $1960, \mathrm{nr} 490,638$.

${ }^{13}$ Wymienione miejscowości leżały w granicach historycznego powiatu pyzdrskiego w ówczesnym województwie kaliskim. Dotychczas publikowane są hasła dotyczące średniowiecznego województwa poznańskiego (zob. Słownik historyczno-geograficzny pozn., 1982-2001).

Za udostępnienie kartoteki, a zwłaszcza za pomoc i fachowe konsultacje składamy bardzo serdeczne podziękowania drowi hab. Tomaszowi Jurkowi i innym pracownikom Pracowni Słownika Historyczno-Geograficznego Wielkopolski przy Instytucie Historii PAN w Poznaniu.

${ }^{14}$ Praca O. Haleckiego Ród Łodziów w wiekach średnich (1911-1913) jest dotąd jedynym całościowym opracowaniem licznych rozgałęzień Łodziów wielkopolskich. Linię właścicieli Kómika przedstawiła w 1969 r. A. Karłowska-Kamzowa $(1969$, s. 5-38, tablica I). Sylwetki wybitniejszych przedstawicieli tego rodu opracowane zostały w Polskim Stowniku Biograficznym; zob. też artykul T. Jurka (1993) o Andrzeju z Bnina - przodku Bnińskich h. Lodzia.

${ }^{15}$ Zob. Gąsiorowski 1970, s. 109, o Benedykcie z Kępy i jego bracie Wojciechu też s. 121, 122. Znane były 2 miejscowości o nazwie Kępa, leżące nad Wartą na południe od Zaniemyśla - Mała i Wiel- 
rodzina Łodziów Błażejewskich wygasła, ,gdyż w 1459 r. Błażejewo należy do Górskich h. Łodzia, w XVI wieku zaś do Bnińskich". Z wyżej cytowanych notatek z 1446 r. wynika jednak, że Błażejewo zostało sprzedane (za 2000 grzywien groszy praskich) wymienionym braciom Górskim. Dalej za O. Haleckim można podać, że: „Andrzej i Benedykt sprzedali w 1459 r. Błażejewo pod Bninem trzeciemu z nich Wojciechowi. Wojciech ten, którego przynależność do rodu Łodzia wyraźnie stwierdza Długosz, poseł Jagiełły do Czech, w r. 1460 kasztelan lądzki i starosta wschowski (1472-1487) jest już niewątpliwym protoplastą tej rodziny" - to jest Górskich h. Łodzia ${ }^{16}$. Tegoż Wojciecha z Błażejewa i Zwoli wymienia też S. Kozierowski pod r. 1464 (dalej pod r. 1578 jako właściciela Błażejewa podaje Jana Bnińskiego).

Dla dziejów interesującej nas miejscowości istotne znaczenie mają teź wiadomości o tutejszej parafii i kościele ${ }^{17}$, który w 1513 r. został za zgodą właściciela Jana z Bnina przyłączony jako filialny do prepozytury bnińskiej ${ }^{18}$.

W wieku XV, do $1513 \mathrm{r}$. Błażejewo było samodzielna, jednowioskową parafią. Pierwsza wzmianka o plebanie (Marku) pochodzi z 1425 r., kolejne z $1429 \mathrm{r}$. (!1482 r.) i 1508 r. ${ }^{19}$ Wezwanie kościoła parafialnego znamy z 1508 r. - 11 tysięcy Dziewic (zapewne św. Urszuli i 11 tysięcy Dziewic) ${ }^{20}$. O skromnym uposażeniu kościoła mówi Liber beneficiorum dioecesis posnaniensis anni 1510 - Księga uposażenia diecezji poznańskiej z roku $1510^{21}$. Można tu jeszcze za S. Kozierowskim dodać, że około $1510 \mathrm{r}$. wieś ta posiadała 8 lanów osiadłych i 4 łany opustoszałe, a dochody proboszcza były bardzo niewielkie (,....tak że dla proboszcza w Bł. mało co zostało i nie mial się z czego utrzymać." $)^{22}$. W 1. połowie XVII w., jak wynika z dokumentów wizytacji kościelnych, wieś była upadła, a drewniany kościół w Błażejewie opuszczony ${ }^{23}$.

ka. Do początków XV w. były one w posiadaniu rodów Doliwów i Wczeliczów. Kępę Wielką sprzedali w 1425 r. Łodzicowi Wojciechowi Górskiemu (Kozierowski 1913; 1914; 1915; 1923, s. 17). J. Nowacki (1964, s. 69) wzmiankuje ją jako dawną posiadłość Wczeliczów, jednak brak tych wiadomości u S. Kozierowskiego (1915, s. 362 - dotyczy parafii Kępa Mała).

${ }^{16}$ Halecki 1912, s. 85, 86.

${ }^{17}$ Wyrażamy wdzięczność śp. ks. drowi Konradowi Lutyńskiemu - dyrektorowi Archiwum Archidiecezjalnego w Poznaniu za egzegezę odnośnych źródel kościelnych, cytowanych w dalszych przypisach.

${ }^{18}$ Kozierowski 1935, s. 22; Nowacki 1964, s. 359.

${ }^{19}$ Archiwum Archidiecezjalne w Poznaniu, Acta causorum Consistorii Posnaniensis - AC 8, k. 243v. z 1425 r.; AC 85, k. 162 z 1508 r.

${ }^{20}$ Tamże, AC 85, k. 162 z 1508 r.; Kozierowski 1935, s. 22; Nowacki 1964, s. 359.

${ }^{21}$ Liber beneficiorum 1950, s. 59 - „Kościół we wsi Błażejewo posiada dziesięć grzywien czynszu rocznego dla plebana, pięć w Kobylinie i pięć w Miłosławiu, a z innych wsi nic nie bierze, ponieważ prepozyt z Bnina bierze dziesięcinę ze wsi Błażejewo; żadnego innego dochodu nie posiada".

${ }^{22}$ Kozierowski 1935, s. 22.

${ }^{23}$ Archiwum Archidiecezjalne w Poznaniu, Acta visitationum Dioecesis Posnaniensis - AV 9 , k. 58 z 1638-1639 r. („Ecclesia parochialis in villa Błażeiewo - desolata”). Dalsze wiadomości o tym 
Należy zatem przyjać sugestię ks. prof. dra Józefa Nowackiego, że ta ,jednowioskowa parafia założona została zapewne $w$ pierwszej połowie XIV wieku, gdy była własnością Grzymałów"24. Nie pozostaje to w sprzeczności z naszymi ustaleniami na temat budowy castrum w Błażejewie, chociaż z przytoczonych wyżej zapisek można wnosić, że funkcjonowanie interesującego nas castrum - fortalicium należy zamknąć $w$ dość wąskich ramach czasowych: początek wieku XV (przed 1422 r.) do 2. połowy XV wieku (po 1459 lub 1464 r., na pewno przed 1513 r., kiedy to Błażejewo przechodzi w ręce Górskich, a kościól staje się filią parafii bnińskiej). Wzniesienie obronnej siedziby mogło mieć miejsce już w 2. połowie XIV w. Można przypisać ją już rodzinie Grzymałów, być może wzmiankowanemu wyżej sędziemu poznańskiemu Mikołajowi piszącemu się z Błażejewa († 1362/1363 r.), który jako jedyny w tej gałęzi Grzymałów pełnił funkcje urzędnicze. Wtedy dokument z 1422 r. można by „odczytywać” jako dotyczący pozyskiwania budulca do odbudowy lub rozbudowy siedziby Małgorzaty z Grzymałów i Łodzica Andrzeja Błażejewskich. Odrębnych poszukiwań w archiwalnych zbiorach kartograficznych wymaga ponadto kwestia zniwelowania i zatarcia w terenie zapewne kopcowatego (okolonego fosa) nasypu ziemnego, na którym stało castrum - fortalicium Błażejewskich.

\section{KOINCYDENCJA ŻRÓDEŁ PISANYCH I ARCHEOLOGICZNYCH}

Terenowe poszukiwania pozostałości przedmiotowego obiektu przeprowadziła grupa archeologów z Instytutu Prahistorii UAM w Poznaniu w sierpniu 2000 r. Wcześniejsze rejestracje stanowisk archeologicznych w rejonie wsi Błażejewo (obecnie administracyjnie należy ona do Błażejewka), położonej przy zachodnim brzegu Jeziora Bnińskiego, dokonane w okresie międzywojennym (por. Muzeum Archeologiczne w Poznaniu, inw. 1927: 428) tudzież w latach 50., 60. i 80. XX w. (MAP, inw. 1950: 294; Katedra Archeologii Polski UAM w Poznaniu, inw. 3/1967; Archeologiczne Zdjęcie Polski 1986, arkusz 56 - 29), ujawniły kilka śladów osadnictwa średniowiecznego $z$ faz D - F (stan. $4,5,6)^{25}$ (ryc. 1 i 2 ). Nie stwierdzono

kościele podaje Kozierowski (1935, s. 22) - „r. 1696 dom B. pod wezw. św. Urszuli znajdował się w nienagannym stanie, podźwignięty r. 1784 przez prob. bnin. Węclewicza stał do r. 1816, kiedy go rozebrano”. W AC 255, k. 137 znajduje się też następująca zapiska z 1817 r.: „Konsystorz Generalny Poznański wyraził zgodę na sprzedaż dominium kórnickiemu drewna z kościółka filialnego w Błażejewie za sumę 100 talarów, pod warunkiem postawienia przez to dominium, w miejsce kościółka, figury krzyża i obsypania wałem samego miejsca gdzie stał kościółek. Pieniądze mają być złożone w kasie kościoła parafialnego w Bninie". Przybliżoną lokalizację kościoła wskazała nam w sierpniu 2000 r. jedna z najstarszych mieszkanek (prawie 90-letnia) wsi; stał on u północnego krańca półwyspu blażejewskiego.

\footnotetext{
${ }^{24}$ Nowacki 1964, s. 359.

${ }^{25}$ Dzieduszyccy 1985.
} 
jednak żadnej formy terenowej, która mogłaby się kojarzyć bezdyskusyjnie z obiektem typu gródka stożkowatego. Na terenie eksponowanego topograficznie stanowiska 4 (półwysep) pobudowano $w$ ostatnich dziesięcioleciach osiedle letniskowe, zajmujące pas szerokości około $100 \mathrm{~m}$, odległy 50-100 m od obecnego brzegu jeziora. W trakcie tych budów nieznacznie wyniesiona terasa została zniwelowana i zniekształcona. Jednak właśnie to miejsce - ze względu na swe naturalne walory obronne - było, jak się wydaje, bardziej niż inne predysponowane do posadowienia średniowiecznej siedziby właścicieli ziemskich. Wzięto przy tym również pod uwagę lokalizację nie istniejącego już kościoła błażejewskiego, który według jednoznacznej tradycji lokalnej znajdował się w pobliżu półwyspu, a domyślnie nieopodal siedziby kolatorów. Wychodząc z tych przesłanek poddaliśmy szczegółowej analizie występujący powierzchniowo na stanowisku 4 ruchomy materiał archeologiczny ${ }^{26}$.

Wobec "obiektywnych" trudności w dotarciu do materiałów archiwalnych, szczególnie średniowiecznych, zdecydowano, że pozyskany ostatnio (2000 r.) zbiór ceramiki można uznać za reprezentatywny. Tak więc stanowić on będzie podstawę rozważań techno-stylistycznych i hipotetycznego datowania stanowiska według tzw. diagnostycznych ułamków naczyń.

Podczas prospekcji powierzchniowej zarejestrowano mocno rozdrobniony materiał ceramiczny, który zalegał mniej więcej równomiernie w obrębie dostępnego do obserwacji wycinka pola uprawnego (niski poziom zasiewów). Niestety, nie udało się zrekonstruować żadnego naczynia, gdyż wszystkie ich ułamki pochodzą wyłącznie z odrębnego segmentu morfologicznego (wylew, brzusiec, dno), co w zasadniczy sposób ogranicza określenie domniemanego kształtu i wielkości pojemnika.

Rutynową analizą techno-stylistyczną objęte zostały wszystkie fragmenty średniowieczne i nowożytne (ceramikę pradziejową pominięto w niniejszym opracowaniu) $)^{27}$. Skromny inwentarz zawiera fragmenty wczesno- i późnośredniowieczne oraz czerepy łączone z wczesno- (XVI - połowa XVII w.) i późnonowożytną (2. połowa XVII-XVIII/XIX w.) produkcja garncarską ${ }^{28}$. Częściowe zniszczenie stanowiska 4 naruszyło układy reliktowe i ich zawartość kulturowa, dlatego materiał ruchomy - pomimo skrupulatnej rejestracji - ma dość ograniczone walory poznawcze. Ostatecznie zdecydowano się na przeprowadzenie analizy formalnej

${ }^{20}$ Ze stanowiska znamy dotąd łącznie 26 fragmentów naczyniowej ceramiki wczesno- i późnośredniowiecznej oraz nowożytnej, tj. 2 ułamki górą obtaczane, 16 fragmentów całkowicie obtaczanych, 8 stalowo-szarych i nowożytnych (Dzieduszyccy 1985, s. 177). Ponadto znaleziono 2 fragmenty naczyń, odłupek korowy z przepalonego ,jaskółczego chlebka" i wiór mikrolityczny z neolitu (Jankowska 1985 , s. 28), kilkadziesiąt skorup i ułamek gładzonego kamienia - kultura łużycka (Fogel 1985, s. 89).

${ }^{27}$ Znaleziono 2 fragmenty brzuśców ceramiki kultury łużyckiej i 3 ułamki naczyń z okresu rzymskiego.

${ }^{28}$ Kruppe 1981; Kajzer 1996, s. 214-218 (tam dalsza literatura). 
ułamków „kuchennych” i „stołowych”, stosując kryteria zaproponowane przez M. Głoska ${ }^{29}$. Ceramikę opracowano zgodnie z przyjętymi schematami, przyporządkowując poszczególne fragmenty do odpowiednich grup i faz ( $\mathrm{z}$ uwzględnieniem techniki wykonania, kształtu i zdobnictwa pojemników) ${ }^{30}$.

Podczas ostatnich badań powierzchniowych (2000 r.) zebrano 62 fragmenty ceramiki, ułamek kafla naczyniowego (?), bryłki polepy i kawałek cegły (współczesna?). Biorąc pod uwagę megaskopowe cechy techno-stylistyczne udało się wydzielić fragmenty naczyń: pradziejowych (5 ułamków), wczesno- (15) i późnośredniowiecznych (28) oraz nowożytnych (14) - por. tabela 1. Poszczególne grupy scharakteryzowano w osobnych podrozdziałach.

\section{CERAMIKA WCZESNOŚREDNIOWIECZNA}

Rozpoznane ułamki częściowo i/lub całkowicie obtaczane (GT II/III) ${ }^{31}$ oraz bardziej progresywne - obtaczane całkowicie na kole garncarskim (GT III) ${ }^{32}$ wykonano z gliny żelazistej, z domieszką tłucznia i/lub piasku. Budowa bryły naczynia, grubość ścianek ${ }^{33}$, a w innych zbiorach również zdobnictwo i proces wypału (utleniający) ${ }^{34}$, uzasadnia podział na te dwie grupy wyrobów, które mogły, acz nie musiały, być wytwarzane i używane w tym samym okresie.

Pozostałości garnków były, niestety, bardzo rozdrobnione. Wśród nich stwierdzono jednak 3 dna $^{35}, 7$ zdobionych brzuśców (ryty poziome) i 1 wylew (ryc. 3: 1-4). Wymienione elementy mikromorfologiczno-stylistyczne skłaniaja, z pewnymi zastrzeżeniami, do datowania tej grupy znalezisk na fazę D-E wczesnego średniowiecza $^{36}$. Trudno rozstrzygnąć, czy są to ślady penetracji osadniczych, czy raczej osady, która funkcjonowała już w fazie $\mathrm{D}_{1}{ }^{37}$.

\section{${ }^{29}$ Glosek 1998, s. 36, 37.}

${ }^{30}$ Hilczerówna 1967; Dzieduszycki 1982; Łosiński, Rogosz 1986, s. 51-61; Buko 1990; Kajzer 1990, s. 11.

${ }^{31}$ Szamałek, Dudziak-Jankowiakowa, Karolczak 1979, s. 88; Dzieduszycki, Fogel 1980, s. 64-70.

${ }^{32}$ Kościńskj 1995, s. 149-196; Sikorski 1995, s. 98-111; Poliński 1996, s. 14-17.

${ }^{33}$ Grubość ścianek GT II/III-0,8 cm; GT III-0,6-0,8 cm.

${ }^{34}$ Przewaga czerepów brązowych (o odcieniu 7.5YR 5/4, 4/4) i żółtawo-czerwonych (5YR 5/6,5/8) - Munsell 1973 - o dwu-trójbarwnych przełamach.

${ }^{35}$ Płaskie (2 egz.) i wklęste (1 egz.) z drobną podsypką mineralną.

${ }^{36}$ Palubicka 1975, tabl. XLII: 1, 7; Szamałek, Dudziak-Jankowiakowa, Karolczak 1979, s. 102 , 169, 228, ryc. 38: 12; 50: 12; 69: 1, 3; Dzieduszycki, Fogel 1980, s. 56-60; ryc. 13: 1-3, 5-8; Dzieduszycki 1982, tab. XV, XVI: Ib; Dzieduszyccy 1985, ryc. 36: 18; 38: 4, 7; 39: 4; Piekalski 1991, s. 102, 103; Kościński 1995, s. 199, 200; Poliński 1996, s. 42-49.

${ }^{37}$ Dzieduszyccy 1985, s. 151, 152. 
Tabela 1

Błażejewo, gm. Kórnik, woj. wielkopolskie, stan. 4. Zestawienie ceramiki naczyniowej i innej

Tabelle 1

Błażejewo, Gem. Kórnik, Woi. Wielkopolska (Großpolen), Fst. 4. Zusammenstellung der Gefảßkeramik und anderer Keramik

\begin{tabular}{|c|c|c|c|}
\hline Ceramika & Grupa technologiczna (GT) & Bliższa specyfikacja & Liczba \\
\hline Starożytna & $\begin{array}{l}\mathrm{kf} \\
\text { or }\end{array}$ & $\begin{array}{l}b \\
b\end{array}$ & $\begin{array}{l}2 \\
3\end{array}$ \\
\hline \multirow[t]{2}{*}{ Wczesnośredniowieczna } & $\mathrm{II} / \mathrm{III}$ & $\begin{array}{l}\mathrm{d} \\
\mathrm{b} \\
\mathrm{w} \\
\mathrm{zd}\end{array}$ & $\begin{array}{l}- \\
2 \\
- \\
-\end{array}$ \\
\hline & III & $\begin{array}{l}\mathrm{d} \\
\mathrm{b} \\
\mathrm{w} \\
\mathrm{zd} \\
\mathrm{p}\end{array}$ & $\begin{array}{l}3 \\
9 \\
1 \\
7 \\
1 \\
\end{array}$ \\
\hline \multirow[t]{4}{*}{ Późnośredniowieczna } & A & $\begin{array}{l}d \\
b \\
w \\
z d \\
p\end{array}$ & $\begin{array}{l}- \\
13 \\
- \\
2 \\
1\end{array}$ \\
\hline & B & $\begin{array}{l}\mathrm{d} \\
\mathrm{b} \\
\mathrm{w} \\
\mathrm{zd} \\
\end{array}$ & $\begin{array}{l}- \\
3 \\
- \\
1\end{array}$ \\
\hline & $\mathrm{C}$ & $\begin{array}{l}d \\
b \\
w \\
z d\end{array}$ & $\begin{array}{l}- \\
5 \\
1 \\
1\end{array}$ \\
\hline & $\mathrm{Cl}$ & $\begin{array}{l}\mathrm{d} \\
\mathrm{b} \\
\mathrm{w} \\
\mathrm{zd}\end{array}$ & $\begin{array}{l}- \\
4 \\
1 \\
5\end{array}$ \\
\hline \multirow[t]{2}{*}{ Nowożytna } & $\mathrm{D}$ & $\begin{array}{l}d \\
b \\
w \\
z d \\
p \\
\end{array}$ & $\begin{array}{l}2 \\
7 \\
- \\
2 \\
1\end{array}$ \\
\hline & $\mathrm{F}$ & $\begin{array}{l}d \\
b \\
w \\
z d\end{array}$ & $\begin{array}{l}- \\
3 \\
1 \\
1\end{array}$ \\
\hline Inne & & $\begin{array}{l}\text { fr. kafla } \\
\text { br. polepy } \\
\text { fr. cegly }\end{array}$ & $\begin{array}{l}1 \\
2 \\
1\end{array}$ \\
\hline
\end{tabular}

L e g e n d a: b - brzusiec, d - dno, w - wylew, zd - zdobiony, p - polewany, k1 - kultura lużycka, or - okres rzymski. 


\section{CERAMIKA PÓŹNOŚREDNIOWIECZNA - NOWOŻYTNA}

Ułamki czerepów z tego okresu stanowią najliczniejszy zbiór (tabela 1). Można w nim wydzielić: (-) fragmenty ceramiki archaicznej, nawiązującej do tradycji garncarstwa wczesnośredniowiecznego (grupa A); (-) ułamki bardziej zaawansowanych technicznie pojemników stalowo-szarych, w wariancie tzw. ceramiki kuchennej (grupa B), stołowej - (grupa C, C1); (-) toczonej ceramiki ceglastej (grupa D); (-) ułamki nowożytne malowane, angobowane $\mathrm{i}$ inne (grupa F).

$\mathrm{Z}$ oczywistych powodów niemoźliwe jest określenie relacji frekwencyjnych pomiędzy poszczególnymi grupami, dlatego ograniczyliśmy się do zwięzłej analizy i hipotetycznej oceny cech techniczno-formalnych, które - z konieczności - stały się przesłanką do wysunięcia wniosków dotyczących datowania tej części zbioru ${ }^{38}$.

Grupa A. „Tradycyjna” ceramika, sygnalizująca jednak częściowe przyswajanie bardziej zaawansowanych umiejętności garncarskich ${ }^{39}$, liczy zaledwie 14 fragmentów, głównie brzuśców. Cienkościenne (o grubości 0,5-0,7 cm), tylko w dwóch przypadkach zdobione „standardowo" czerepy (ryc. 1: 12) wypalono w atmosferze utleniającej (ścianki o odcieniu brunatnym - 7.5YR 5/4, 6/4 i czerwonawo-żółtym $5 Y R 6 / 6,6 / 8)$ pochodzą zapewne $z$ wielofunkcyjnych pojemników ceramicznych, jakie znamy $\mathrm{z}$ inwentarzy XIII/XIV-XV $w{ }^{40} \mathrm{Na}$ uwagę zasługuje ułamek dzwonowatej (?) pokrywki obejmującej (ryc. 3: 11) - typowego elementu ceramiki „kuchennej", zarówno w grupie wyrobów utleniających, jak i redukcyjnych (gdzie bywają popularniejsze $)^{4}$.

Grupa B. Fragmenty zaliczone do tej grupy technicznej są poświadczone śladowo. Przypuszczalnie wykonano je z gliny żelazistej (z domieszką średnio- i drobnoziarnistego piasku), były silnie formująco obtaczane $\mathrm{i} /$ lub podtaczane (technika taśmowo-ślizgowa) oraz wypalane $w$ atmosferze ze zredukowanym dostępem tle$\mathrm{nu}^{42}$. Na jednym z brzuśców rozpoznano wytartą linię falistą (ryc. 3: 8), która nawiązuje do ,archaicznych" sposobów zdobienia, także siwaków, stosowanych jeszcze w połowie $\mathrm{XV} \mathrm{w}{ }^{43}$

Grupa C. Późnośredniowieczne ułamki „delikatniejszej” ceramiki (o grubości ścianek $0,6-0,7 \mathrm{~cm}$ ), uformowane i wypalone jak wyroby grupy B i C1, miały powierzchnie staranniej wygładzone i ciemniejsze (o odcieniu szarym i/lub ciemnoszarym - 10YR 5/1, 4/1). Zapewne jest to stłuczka lepszych, może „stołowych” pojemników (brak niedosiwień i jednobarwne przełamy) ${ }^{44}$. Ułamki zdobione poziomą linią

\footnotetext{
${ }^{38}$ Kajzer 1991, s. 469-482.

${ }^{39}$ Rzeźnik 1998, s. 121-127; Niegoda 1999, s. 159, 160.

${ }^{40}$ Szamałek, Dudziak-Jankowiakowa, Karolczak 1979, s. 246; Grygiel, Jurek 1994, ryc. 209: 5.

${ }^{41}$ Poliński 1996, s. 204, 205; Niegoda 1999, s. 172, 173, ryc. 39.

${ }^{42}$ Grubość ścianek 0,6-0,9 cm; powierzchnia o odcieniu szarym i szaro-brunatnym - 10YR 5/1, 5/2.

${ }^{43}$ Kruppé 1961, s. 62; Marciniak-Kajzer, Nowakowski 1999, s. 261-263.

${ }^{44}$ Kruppé 1961, s. 96; Kajzer 1994, s. 9-14; Fryś-Pietraszkowa 1994, s. 15-19; Niegoda 1999. s. 158-160; Poliński 2000, s. 115-129.
} 


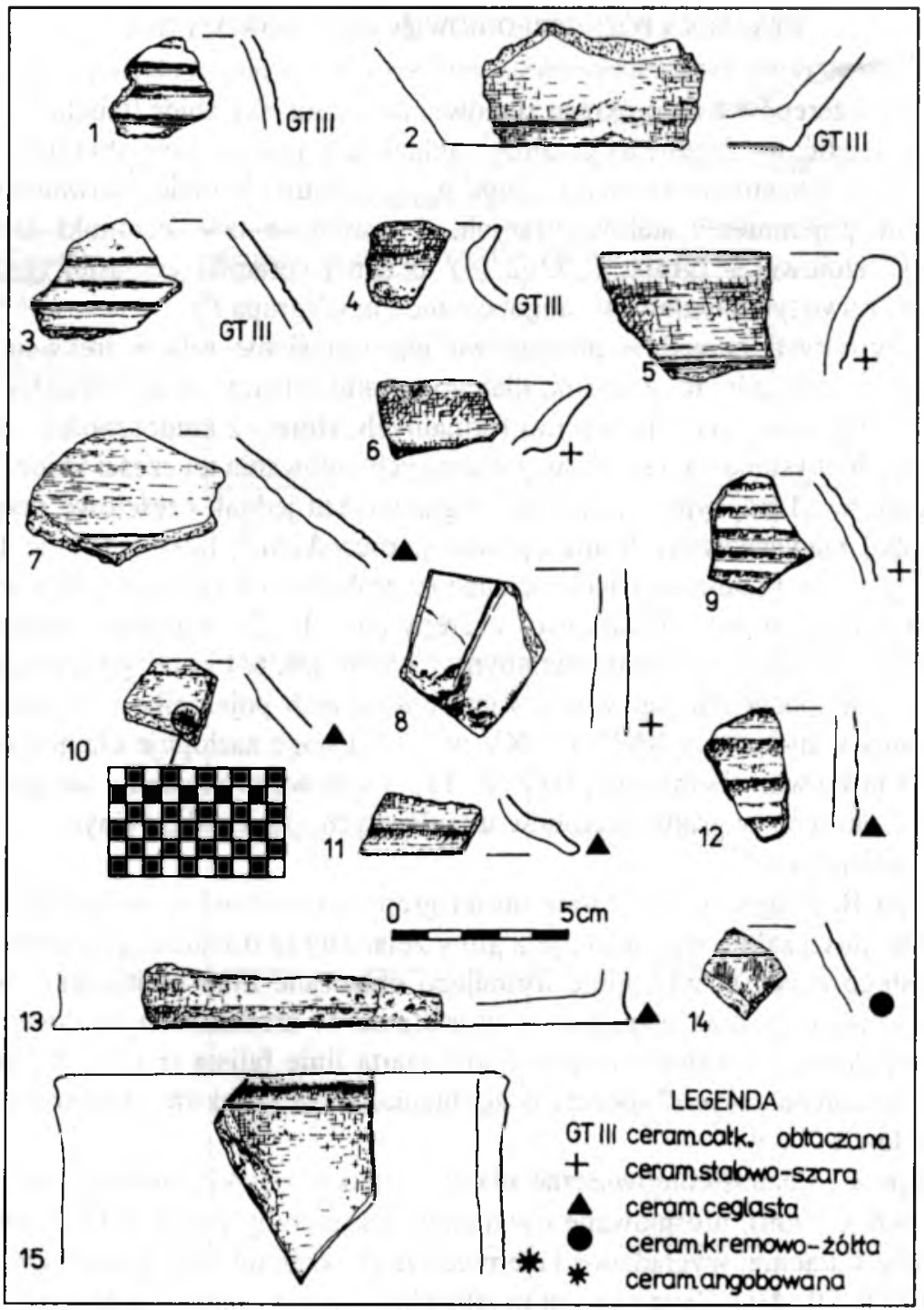

Ryc. 3. Błażejewo, gm. Kórnik, woj. wielkopolskie, stan. 4. Wybór ceramiki naczyniowej z badań powierzchniowych (sierpień 2000 r.). Ułamki wczesnośredniowiecznych naczyń całkowicie obtaczanych na kole garncarskim (GT III): 1-4; późnośredniowieczna ceramika stalowo-szara: 8 (grupa B), 6, 9 (grupa C), 5 (grupa $\mathrm{Cl}$ ); późnośredniowieczna i/lub nowożytna ceramika ceglasta: 12 (grupa A), 7, 10, 11, 13 (grupa D); fragmenty ceramiki kremowo-żóltej i angobowanej: 14, 15 (grupa F). Rys. O. Antowska

Abb. 3. Błażejewo, Gem. Kómik, Woi. Wielkopolska (Großpolen). Fst. 4. Tongefaßauswahl aus der archäologischen Landesaufnahme (August 2000). Fragmente der frühmittelalterlichen auf Töpferscheibe völlig abgedrehten Gefäße (GT III): 1-4; spätmittelalterliche stahlgraue Keramik: 8 (Gruppe B), 6, 9 (Gruppe C), 5 (Gruppe C1); spätmittelalterliche und/oder neuzeitliche ziegelfarbige Keramik: 12 (Gruppe A), 7, 10, 11, 13 (Gruppe D); Fragmente der cremefarbenen und gelben Keramik sowie der Keramik mit zusätzlicher, dünner Tonschicht von außen: 14, 15 (Gruppe F). Gez. O. Antowska 
i wylew siwaka, pochodzące zapewne z garnka lub dzbana? (ryc. 3: 6, 9), moga stanowić - $z$ określonymi zastrzeżeniami - przykłady takich właśnie pojemników ${ }^{45}$. Najogólniej znaleziska te datować można na XIV-XV wiek ${ }^{46}$.

Grupa C1. Osobno - zgodnie z sugestiami M. Gloska - opisano fragmenty „ekskluzywnej” ceramiki redukcyjnej ${ }^{47}, \mathrm{z}$ poziomo lub ukośnie wyświecanymi płaszczyznami (liniami) (ryc. 3: 5) ${ }^{48}$. Zwykle uznaje się, iż siwaki polerowane reprezentują stosunkowo wysoki poziom umiejętności garncarskich, świadcząc tym samym o preferencjach estetycznych XIV-XV-wiecznych nabywców ${ }^{49}$.

Grupa D. Skromny zbiór fragmentów wypalonych w zaawansowanej atmosferze utleniającej ${ }^{50}$ może być nieco zawyżony, gdyż przy opracowywaniu rozdrobnionego materiału mogliśmy błędnie zaklasyfikować tutaj ułamek niecałkowicie pokrytego polewą pojemnika (a znamy wiele takich form). Dwa dna, odcinane od koła garncarskiego (ryc. 3: 14), fragment pokrywki stożkowatej (ryc. 3: 7) i standardowe zdobienie brzuśców (poziome ryty) toczonych (?) sugerują że są to resztki naczyń konwencjonalnie młodszych i/lub eksploatowanych z siwakami (XV-XVI w.?) ${ }^{51}$.

$\mathrm{Na}$ jednym z brzuśców rozpoznano negatyw tkaniny (aneks 1 ). Wydaje się, że jest to odcisk szmaty, którą garncarz wyrównywal (przecieral) zewnętrzną i wewnętrzną powierzchnię ścianki utoczonego, acz ciągle plastycznego naczynia (ryc. 3: 10). Ów negatyw produkcyjny jest interesujący z kilku powodów: $(-)$ mogła to być sztywna tkanina płócienna $1 / 1$, gatunku I; (-) wykonano ja zapewne na krośnie poziomym; (-) nie można wykluczyć, iż było to sukno, które wtórnie wykorzystano w warsztacie garncarskim ${ }^{52}$. Pośrednio więc ceramika w jakiś sposób wzbogaciła źródła o wyrobach włókienniczych, które - ze względu na stan zachowania - pozostają nadal słabo rozpoznane.

Grupa F. Zaliczono tutaj 4 fragmenty, które były toczone na kole garncarskim. Zasadniczo grubość ich ścianek nie przekraczała $0,6-0,7 \mathrm{~cm}$ (niezależnie od ostatecznego wykończenia powierzchni), natomiast kolory tworzywa ceramicznego pod malaturą (2.5YR 6/8) lub warstwą angoby (10YR 6/2) różnily się, odzwierciedlając odmienne warunki wypału. Trudno rozstrzygnąć, czy rzeczywiście ułamek misy (?) został pomalowany na biało, czy raczej są to ślady pobiały. $Z$ kolei fragmenty angobowanego dzbana? (ryc. 3: 15) nie zostały dobrze wypalone, niewykluczone więc, że miał to być podkład pod szkliwo, nie zaś samodzielna powłoka (jaką pokrywano

\footnotetext{
${ }^{45}$ Marciniak-Kajzer, Nowakowski 1999, s. 261, ryc. 4.

${ }^{46}$ Sulkowska-Tuszyńska 1997, s. 62 (tam dalsza literatura).

${ }^{47}$ Glosek 1998, s. 36, 37.

${ }^{48}$ Grubość ścianek 0,4-0,6 cm; powierzchnia o odcieniu szarym i ciemnoszarym - 10 YR 5/1, 4/1.

${ }^{49}$ Grygiel, Jurek 1994, s. 30, ryc. 121:3; 122: 5; 123:5, 6; Sulkowska-Tuszyńska 1997, s. 67.

${ }^{50)} \mathrm{O}$ odcieniu czerwonawo-żóltym (7.5YR 6/6 i 6/8) i jasnoczerwonym (2.5YR 6/6 i 6/8); grubości
} den $0,7-0,8 \mathrm{~cm}$ i ścian $0,4-0,6 \mathrm{~cm}$.

${ }^{51}$ Sulkowska-Tuszyńska 1997, s. 62, 63.

${ }^{52}$ Maik 1997; Sikorski 1998, s. 191-195; 2000. 
ceglaste naczynia toczone od XIV/XV po XVIII w. $)^{53}$. Interesującym znaleziskiem jest również fragment brzuśca kremowo-żółtego (ryc. 1: 14), który wykonany został $\mathrm{z}$ delikatnej glinki kaolinitowej (ścianka zewnętrzna przecierana pędzelkiem) - wyrób niekoniecznie łączony $z$ ośrodkami południowej Polski (?) ${ }^{54}$.

Kafle. Znaleziono także fragment kafla naczyniowego o otworze prostokątnym. Zły stan zachowania tego prostego kafla nie upoważnia do wyciagania wniosków co do urządzeń grzewczych, ich wyglądu i funkcjonowania, jakkolwiek wiadomo, że podobne kafle były stosowane w XV-XVI stuleciu i później ${ }^{55}$.

Wnioski. Na podstawie obserwacji makroskopowej cech techno-stylistycznych niewielkiego, acz reprezentatywnego zbioru ułamków naczyń ceramicznych zebranych na stanowisku 4 w Błażejewie, nasuwa się kilka uwag. Głównie dotyczą one wytwórczości (produkcji) garncarskiej, a konkretnie silnie rozdrobnionego materiału. Wiadomo bowiem, że ceramika jest źródłem tyleż masowym, co często mało przydatnym do badań niektórych aspektów społecznych, gospodarczych i kulturowych - nie tylko w średniowieczu i nowożytności ${ }^{56}$. Respektując powyższe zastrzeżenia i korzystając $\mathrm{z}$ wypracowanych wcześniej kryteriów podziału tych źródeł (i sposobu definiowania wyróżnianych cech i walorów) wydzielono kilka grup, które - z dużym prawdopodobieństwem - zaliczyć można do inwentarzy ruchomych zwiazanych z penetracja, eksploatacją lub okupacją naturalnie dogodnego miejsca $w$ Niecce Jezior Bnińskich ${ }^{57}$, na terenie określonym jako stan. 4 w Błażejewie. Ostatecznie stwierdzono więc fragmenty naczyń: (-) pradziejowych (kultura łużycka, okres rzymski); (-) wczesnośredniowiecznych (faza D-E i częściowo F - 24,2\% analizowanego zbioru); (-) późnośredniowiecznych (XIV-XV/XVI w. - 45,1\%) i nowożytnych (XV/XVI w., z elementami późniejszymi - 22,6\%). Warto też zwrócić uwagę na ulamek kafla prostego, który - mimo nieprecyzyjnej datacji - może zaświadczać o randze tutejszego domniemanego obiektu obronno-mieszkalnego, gdyż piece od połowy XIV w. „,stawiano w pomieszczeniach zamkowych, domach miejskich i siedzibach wiejskich osób w tym środowisku uprzywilejowanych"58.

\section{UWARUNKOWANIA ŚRODOWISKOWO-GEOGRAFICZNE}

Jak już wspomnieliśmy wyżej, półwysep błażejewski stanowi wyróżniającą się nawet w skali szerszej okolicy - rzadką formę terenową (ryc. 1 i 2). Ma w przybliżeniu kształt trójkąta równobocznego o podstawie liczącej około $300 \mathrm{~m}$. Jego hipso-

${ }^{53}$ Sulkowska-Tuszyńska 1997, s. 64.

${ }^{54}$ Poliński 1996, s. 204; Sulkowska-Tuszyńska 1997, s. 64; Dziubek, Ruta 1999, s. 298, 299.

${ }^{55}$ Kirchhoff 1994, s. 15-17; Mizerka 1994, s. 41-44; Łaszkiewicz 1997, s. 21-38; Dymek 1995, s. 41,42 .

${ }^{56}$ Rzeźnik 1998, s. 121-130.

${ }^{57}$ Nowaczyk 1985.

${ }^{58}$ Dąbrowska 1987, s. 215; Łaszkiewicz 1997, s. 7 n. 


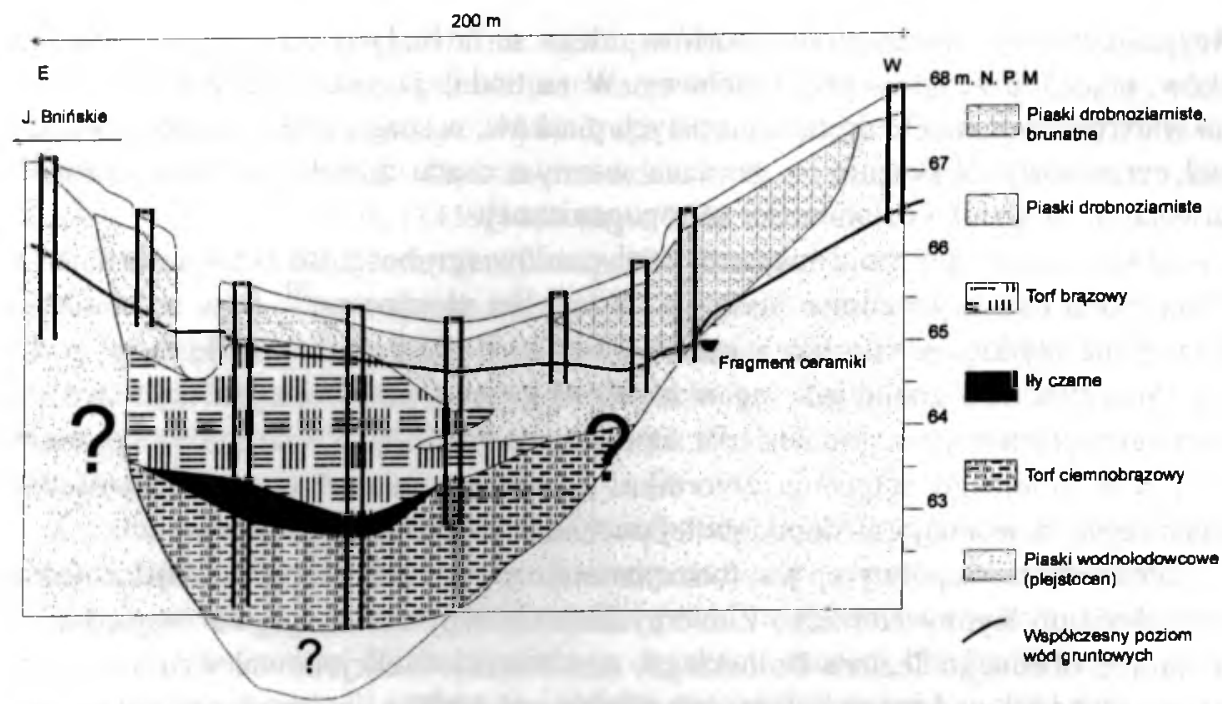

Ryc. 4. Błażejewo, gm. Kórnik, woj. wielkopolskie, stan. 4. Przekrój geologiczny przez zachodnią terasę Jeziora Bnińskiego (por. ryc. 1B). Rys. J. Jasiewicz

Abb. 4. Błażejewo, Gem. Kórnik, Woi. Wielkopolska (Großpolen). Fst. 4. Geologischer Querschnitt durch die Westterasse des Bnińskie Sees (vgl. Abb. 1 B). Gez. J. Jasiewicz

metrię cechuje niewielkie zróżnicowanie (66,8-71,2 m n.p.m.). Po obwodzie znajdują się partie silnie podmokłe, zalewane przy wyższych stanach lustra Jeziora Bnińskiego. Od zachodu półwysep ogranicza południkowo zorientowane obniżenie, przez które prowadzi dziś rów odwadniający. Środkowa część półwyspu, nieznacznie morfologicznie akcentowana, jest wyniesiona, sucha, piaszczysta. Od północnego wschodu przylega do niej prostokątne w planie, podobnie wysokie plateau.

W celu rekonstrukcji pierwotnego (średniowiecznego) ukształtowania półwyspu błażejewskiego wykonano w 2000 r. sondaż geologiczny (por. ryc. 1B i 4).

Wykazał on istnienie rozległego i głębokiego obniżenia wypełnionego osadami torfowymi. W rzeźbie powierzchni obniżenie to zaznacza się dwiema wyraźnymi krawędziami morfologicznymi, o względnej wysokości około $0,5 \mathrm{~m}$, zarówno od strony wschodniej (jeziora), jak i od strony zachodniej. Samo obniżenie jest wypełnione osadami torfowymi o miąższości przekraczającej $4,4 \mathrm{~m}$. W czasie teraźniejszych badań terenowych nie udało się osiagnąć spagu serii torfowej, jednakże wykonane wcześniej obserwacje wskazują, że miąższość serii organicznej może przekraczać nawet $6 \mathrm{~m}$ (informacja ustna dra Adama Wojciechowskiego z Instytutu Badań Czwartorzędu i Geoekologii UAM w Poznaniu). W spagu są to ciemnobrązowe, dobrze rozłożone torfy, o miąższości co najmniej $2 \mathrm{~m}$. Przykryte sa około 0,7-metrowej miąższości warstwą czarnych, plastycznych iłów. Powyżej warstwy ilastej zalega 2-metrowej miąższości seria jasnobrązowych torfów z zachowanymi szczątkami roślinności. Są to resztki trzcin i roślin bagiennych i plytkowodnych. 
Bezpośrednio na brązowej serii torfów zalega seria białych lub jasnożółtych piasków, przechodzących w profil glebowy. W zachodniej części przekroju stwierdzono warstwę brunatnych, drobnoziarnistych piasków, w spagu której napotkano materiał ceramiczny. Wskazuje to, że dana warstwa osadu została przekształcona lub utworzona w wyniku działalności antropogenicznej.

Obecność w obniżeniu miąższej serii osadów (grubości do $6 \mathrm{~m}$ ) wskazuje, że dana forma była wypełniona wodą już od schyłku plejstocenu ${ }^{59}$. Było to obniżenie relatywnie płytkie, gdyż tylko w takich warunkach mogły tworzyć się osady torfowe. Warstwa iłów znajdująca się w środkowej części przekroju jest najprawdopodobniej zapisem okresu podniesienia się lustra wody. Kolejna seria torfowa powstała w czasie kolejnego spłycenia zbiornika. Zalegająca na torfach warstwa osadów piaszczystych jest najprawdopodobniej pochodzenia antropogenicznego.

Przedmiotowy półwysep jest formą naturalna, pozostałą po późnoplejstoceńskim rozgałęzieniu Rynny Kórnicko-Zaniemyskiej. Główny nurt odpływu znajdował się w niecce obecnego Jeziora Bnińskiego, nurt boczny funkcjonował wzdłuż dzisiejszego zachodniego brzegu jeziora, między innymi wzdłuż wspomnianego obniżenia. Dowodem tego jest przekrój wykonany przez A. Wojciechowskiego ${ }^{60}$, około $3 \mathrm{~km}$ dalej na południe, gdzie jest zachowana podobna struktura, wypełniona materiałami organicznymi. Niwelacja szczytowej części osadów półwyspu, związana z budową osiedla letniskowego, nie pozwala stwierdzić, jaka była pierwotna wysokość kulminacji i czy była ona w średniowieczu nadbudowana.

Studium A. Wojciechowskiego dowodzi, że poziom lustra Jeziora Bnińskiego w XV w. był około $1 \mathrm{~m}$ niższy od średniej obecnej ${ }^{61}$. Tym samym powierzchnia półwyspu - wobec płytkości partii przybrzeżnej jeziora - była wówczas wyraźnie większa.

\section{PODSUMOWANIE}

„Nowo odkryte" dla archeologów źródło historyczne (KDW, t. VIII, nr 935, datowane 9 marca 1422 r.) traktuje o późnośredniowiecznym castrum w Błażejewie (gm. Kórnik, woj. wielkopolskie), naprawianym lub rozbudowywanym raczej niż dopiero wznoszonym ${ }^{62}$ przez właściciela - Andrzeja Błażejewskiego, wywodzacego się - jak się wydaje - z Łodziców Bnińskich, wżenionego w ród Grzymalitów. Wszechstronne - choć ograniczone stanem źródeł pisanych - kwerendy genealogiczno-własnościowe (rozdz. 1) pozwalają przypisać hipotetycznie założenie owej

\footnotetext{
${ }^{59}$ Wojciechowski 1999.

${ }^{60}$ Wojciechowski 1999.

${ }^{61}$ Wojciechowski 1999, s. 92, ryc. 7.

${ }^{62}$ Znamienne jest wymienienie $w$ tym dokumencie drogi ,potocznie zwanej $\mathrm{ku}$ wało m", co oznacza, że zarówno ona, jak i „wały” istniały przed rokiem 1422, i to kilkadziesiąt lat, potrzebnych na utrwalenie się tego toponimu.
} 
siedziby w Błażejewie Grzymalitom, może personalnie Mikołajowi z Błażejewa, już w 2. połowie XIV w. Jednak funkcjonowanie obiektu opisanego w wyżej wymienionym dokumencie, stanowiące chyba drugą fazę tutejszego castrum - fortalicium, należałoby zamknąc $\mathrm{w}$ dość wąskim przedziale czasowym: początek XV w. (przed 1422 r.) - 2. połowa $X V$ w. (1459/1464 aż po 1513 r.).

Z dziejami obronnej rezydencji naprzód Grzymalitów, a później Łodziców w Błażejewie oczywisty związek ma historia tutejszej parafii i kościoła. Jednowioskowa parafia błażejewska, dysponująca drewnianą świątynią, mogła być erygowana już w 1. połowie XIV w. (według J. Nowackiego). Jej funkcjonowanie na przestrzeni całego wieku XV nie ulega wątpliwości. W 1513 r. została ona inkorporowana do prepozytury bnińskiej (rozdz. 1).

Zasadniczy dla nas dokument z 1422 r. informuje dość szczegółowo o niektórych elementach rezydencji w Błażejewie. Jest nim mowa o ,....wszelkich odpowiednich budowlach w miejscu warownym (castri) i przed miejscem warownym (ante castrum) [...], mianowicie domach, wieży $\mathrm{z}$ daszkami inaczej blankami, rowie [z?] drogą dylowaną (pons)...”, a także o „...drodze potocznie zwanej k u w a ł o m...".

Koincydencja danych historycznych, archeologicznych i geologicznych, odnoszących się do błażejewskiego castrum, stała się możliwa dzięki prospekcjom terenowym dawnym oraz tym z 2000 r. (rozdz. 2 i 3). W ich wyniku wytypowano - jako najbardziej prawdopodobną - lokalizację poszukiwanego obiektu - stanowisko 4 w Błażejewie, położone na półwyspie Jeziora Bnińskiego, zdecydowanie wyróżniającego się topograficznie w okolicy (rozdz. 1 i 2). Choć na tymże stanowisku nie udało się zaobserwować żadnych resztek postbudowlanych, to jednak zwrócono uwage na duży, naturalny walor obronny miejsca oraz utrwalona jednoznacznie w lokalnej tradycji ustnej lokalizację dawnego kościoła w pobliżu rzeczonego półwyspu, a więc domyślnie nieopodal rezydencji.

Pozyskany powierzchniowo materiał ceramiczny (ułamki naczyń), w wystarczająco liczebnej próbie reprezentatywnej, składał się z okazów pradziejowych, wczesnośredniowiecznych (fazy D - E i F), późnośredniowiecznych (XIV-XV/ /XVI w.), nowożytnych (XV-XVI w.) i nam współczesnych (tabela 1). Godny podkreślenia jest fakt, że $w$ analizowanym zbiorze ceramika późnośredniowieczna ma udzial największy $(45,1 \%)$.

Zbadany profil geologiczny stanowiska 4 (rozdz. 3, ryc. 1B i 4) dowodzi, że środkowa, piaszczysta i zawsze sucha partia półwyspu była wyniesiona ponad otoczenie. Występujące u nasady półwyspu obniżenie okazało się formą naturalną, genetycznie późnoplejstoceńską, wypełnioną bardzo grubymi osadami torfowymi, powstałymi w warunkach wielowiekowego podtopienia. Jeśli dodamy, że w XV wieku lustro Jeziora Bnińskiego leżało $1 \mathrm{~m}$ niżej niż obecnie, to możemy twierdzić, iż obszar półwyspu był wówczas wyraźnie większy oraz że spełniał - jak na owe czasy kryterium wysokiej obronności. Wspomniane obniżenie, wypełnione wodą i torfami, odcinało bowiem półwysep od „lądu stałego", funkcjonując najpewniej jako fosa (ewentualnie niewiele skorygowana inżynieryjnie „przekopa”, obudowana drewnem?). 
Jak wynika z wnikliwych studiów L. Kajzera, późnośredniowieczne rezydencje mające charakter mieszkalno-obronny bardzo często przybierały formę drewnianych dworów (i towarzyszących budowli gospodarczych), posadowionych na „kopcach” ziemnych, nazywanych przez archeologów gródkami stożkowatymi. Obiekty te nawiązywały do ogólnoeuropejskiego modelu warowni typu motte. W Polsce forma ta kulminowała frekwencyjnie w XIV wieku, była nieco rzadsza w następnym stuleciu, a przeżywała się sporadycznie nawet do XVIII wieku. „W wieku XV, gdy możni zaczęli się przenosić ze swych starych obronnych dworów i drewnianych wież do murowanych zamków, siedziby takie były zamieszkiwane nadal przez biedniejszą i średnią szlachtę. Sąd taki jest zapewne generalnie prawdziwy, nie może jednak prowadzić do sugestii, że walor prestiżowy małej obronnej siedziby drewnianej był nieznaczny”. Uwaga ta dotyczy również sytuacji w Wielkopolsce. „Ówczesne określenie castrum, często spotykane w przekazach z XV wieku, równie dobrze oznacza zespół dużego murowanego zamku, jak i użyte być może dla opisu całkowicie drewnianego zespołu dworskiego, jednakże otoczonego częstokołem [nazywanego też wałem - dop. J.F.] i ulokowanego na nasypie ziemnym". Często do obwarowań należała także fosa. „Obronność tych dworów miała znaczenie jedynie w sferze całkowicie lokalnej. Chronić one miały przed atakiem niespokojnego sąsiada, nie zaś stanowić punkt oporu w trakcie działań wojennych"63.

Jak wykazują badania archeologiczne, powołane przez cytowanego wyżej autora, „dwory na kopcach" cechowało duże zróżnicowanie strukturalne. W świetle tego faktu trudno kusić się - z braku odnośnych danych - o bliższą klasyfikację domniemanego gródka obronnego $w$ Błażejewie. W sferze domysłów pozostaje nawet obecność nasypu ziemnego - „kopca”. Ze źródła pisanego wiemy natomiast, że w obrębie „miejsca warownego" znajdowała się nie jedna, a więcej budowli drewnianych. Najważniejsza z nich była wieża mieszkalna, zapewne - jak podpowiadaja analogie - kilkuetażowa, zwieńczona blankami. Stawiamy ostrożnie hipotezę, że innym elementem zabudowy był „folwark" ${ }^{, 64}$, zlokalizowany na plateau położonym na północny wschód od wieży (rozdz. 3, ryc. 1B). Dyskusyjna jest postać samych obwarowań. Z kontekstu topograficznego zdaje się wynikać, że nie musiały mieć one zamkniętej formy obwodowej, a jedynie odcinkową zabezpieczającą dwór od strony zachodniej, czyli od „lądu stałego". W drugim przypadku - bardziej prawdopodobnym - elementem obronnym była omówiona wyżej „fosa”. Nie wiadomo, czy od zewnątrz towarzyszył jej wał ziemny i/lub częstokół (por. analogie). Poza strefą obronną (ante castrum) istniały jakieś budynki, może o charakterze gospodarczym. Od wsi „ku wałom” wiodła dylowana droga, przekraczająca „fosę” po pomoście.

Nie potrafimy określić relacji obiektu błażejewskiego do innych ,podobnych", znajdujących się na obszarze Niecki Jezior Bnińskich. Mamy na myśli dwa

${ }^{63}$ Kajzer 1993, s. 152-157, 171-177; 1996, s. 113 n., 125-139; Kóčka-Krenz 1993 (szczególnie s. 294, ryc. 1 - kartogram).

${ }^{64}$ Np. Fogel 1995, s. 48-51, ryc. 11, 12 (Kępno). 
gródki stożkowate: w Bninie (gm. Kórnik, stan. 1) ${ }^{65}$ i w Łęknie (gm. Zaniemyśl, stan. 2) ${ }^{66}$.

Pierwszy z nich, położony na półwyspie „Szyja”, w sąsiedztwie grodu pierścieniowatego (stan. 2a), był badany wykopaliskowo w latach 60 . XX w. Pozostałości naszczytowej wieży zachowały się szczątkowo. Na zboczu „kopca” odkryto obfite resztki budowli gospodarczej ( $\mathrm{z}$ dużym zapasem zbóż), strawionej pożarem. „Kopiec" pierwotnie otaczała palisada. Gródek bniński jest datowany materiałem ceramicznym i pośrednio źródłami pisanymi na 2. ćwierć - koniec XIII w. Zdaniem monografisty E. Krauzego ${ }^{67}$ pełnił on funkcję fermety, broniącej dostępu do właściwego grodu (stan. 2a) w ostatniej fazie jego istnienia. Ówczesny zespół fortyfikacyjny mógł wchodzić w skład ogólnopaństwowej sieci obronnej, zważywszy, że Bnin był kasztelanią. W tej sytuacji gródek stożkowaty nie musial być siedzibą lokalnego posesjonata. Na marginesie dodajmy, że nie udało się dotąd zlokalizować późniejszej, XIV-wiecznej rezydencji Łodziców Bnińskich, znanych ze stosunkowo licznych wzmianek w dokumentach.

Gródek stożkowaty w Łęknie, posadowiony na skraju terasy Niecki Jezior Bnińskich, jest rozpoznany tylko sondażowo. Nie odnotowano tu żadnych pozostałości budowli, nie licząc intensywnej spalenizny, sugerującej zniszczenie pożarowe. Materiał ceramiczny wskazuje czas od połowy XIII do początku XIV wieku jako prawdopodobny okres funkcjonowania tego fortalicium.

W odniesieniu do toczącej się od kilkudziesięciu lat dyskusji na temat wykorzystania Niecki Jezior Bnińskich jako kombinowanej - naturalnej i umocnionej - linii obronnej w momencie ataku Krzyżaków na Wielkopolskę na przełomie lipca i sierpnia 1331 roku, opisanego przez Jana Długosza, możemy stwierdzić, że gródki stożkowate w Bninie i Łęknie były już wtedy w ruinie, zatem nie mogły stanowić punktów czynnego oporu (podobnie rzecz się miała $\mathrm{z}$ grodami pierścieniowatymi w Bninie i Kępie Wielkiej oraz domniemanym grodem na Wyspie Edwarda w Zaniemyślu) ${ }^{68}$. Natomiast castrum Grzymalitów w Błażejewie jeszcze nie istniało.

\section{ANEKS}

Błażejewo, gm. Kórnik, woj. wielkopolskie, stan. 4

Slabo czytelny, płytki „negatyw” tkaniny na zewnętrznej powierzchni fragmentu brzuśca nowożytnego naczynia ceramicznego (grupa A - por. Kajzer 1990, s. 11). Wymiary odcisku: $3 \times 4 \mathrm{~mm}$. Barwa? Budowa tkaniny: splot płócienny 1/1, typ I lub la (Maik 1988, s. 62-65), gatunek I.

\footnotetext{
${ }^{65}$ Krause 1976.

${ }^{66}$ Fogel 1975, s. 151, 152; Studia i Materiały 1959, s. 258.

${ }^{67}$ Krause 1976, s. 99, 100.

${ }^{68}$ Fogel 1975, s. 148-157; Studia i Materiały 1995, s. 393, 394 (Zwola).
} 
D a tow an i e: XV/XVI wiek.

Uw a gi: odcisk produkcyjny, ślady finalnego wygladzania szmatką zewnętrznej powierzchni ścianki naczynia.

\begin{tabular}{|c|c|l|c|l|}
\hline Osnowa-wątek & Gęstość & \multicolumn{1}{|c|}{ Grubość przędzy } & Skręt & \multicolumn{1}{c|}{ Surowiec } \\
\hline Osnowa & 22 nici na $1 \mathrm{~cm}$ & $\begin{array}{l}0,250-0,300 \mathrm{~mm} \\
\text { średnia: } 0,285 \mathrm{~mm}\end{array}$ & $\mathrm{Z}$ & $\begin{array}{l}\text { welna?; grub. wł. } 0,012 \mathrm{~mm} \text { ? } \\
\text { średnia: } 0,012 \mathrm{~mm}\end{array}$ \\
\hline Wạtek & 20 nici na $1 \mathrm{~cm}$ & $\begin{array}{l}0,350-0375 \mathrm{~mm} \\
\text { średnia: } 0,365 \mathrm{~mm}\end{array}$ & $\mathrm{Z}$ & $\begin{array}{l}\text { welna?; grub. wł. } 0,012 \mathrm{~mm} \text { ? } \\
\text { średnia: } 0,012 \mathrm{~mm}\end{array}$ \\
\hline
\end{tabular}

\section{BIBLIOGRAFIA}

B u ko A.

1990 Ceramika wczesnopolska. Wprowadzenie do badań [Sum. Introduction into research of the early medieval Polish pottery], Wrocław.

Dąbrowska M.

1987. Kafle i piece kaflowe w Polsce do końca XVIII wieku [Sum. Tiles and tile stoves in Poland to the end of the XVIII ${ }^{\text {th }}$ century], Wrocław - Warszawa - Gdańsk - Lódź.

D y m e k K.

1995 Średniowieczne i renesansowe kafle ślqskie, Wrocław.

Dzieduszyccy B. iW.

1985 Osadnictwo wczesnośredniowieczne w rejonie Niecki Jezior Bnińskich [Zus. Das frühmittelalterliche Siedlungswesen in der Region der Mulde der Bnin-Seen], (w:) Materiaty do studiów nad osadnictwem bnińskim. Mikroregion bniński (red. J. Żak i J. Fogel), Poznań, s. 141-197.

Dzieduszycki W.

1982 Wczesnomiejska ceramika kruszwicka w okresie od 2 potowy X w. do potowy XIV w. [Sum. The early-urban Kruszwica ceramics from the second half of the $10^{\text {th }}$ to the mid- $14^{\text {th }}$ centuries], Wrocław - Warszawa - Kraków - Gdańsk - Łódź.

Dzieduszycki W., Fogel J.

1980 Gród wczesnośredniowieczny w Śremie [Sum. An early-mediaeval fortlet in Śrem], „Slavia Antiqua", t. XXVI, s. 33-91.

Dzi ubek E., Ruta S.

1999 Zabytki archeologiczne $z$ dworu w Pabianicach [Sum. Archaeological relicts in the castle in Pabianice], „,Lódzkie Sprawozdania Archeologiczne”, t. V, s. 297-307.

Fogel J.

1975 W kwestii „Walów Zaniemyskich”, „Studia i Materialy do Dziejów Wielkopolski i Pomorza", z. 22, s. 141-157.

1985 Przemiany osadnictwa mikroregionu bninskiego $w$ epoce brazu $i$ wczesnych okresach epoki zelaza [Zus. Die Umwandlungen des Siedlungswesens der Bnin-Mikroregion in der Bronzezeit und in den frühen Perioden der Eisenzeit], (w:) Materiały do studiów nad osadnictwem bnińskim. Mikroregion bniński (red. J. Żak i J. Fogel), Poznań, s. 35-118.

1995 Tematy archeologiczne $w$ rysunkach $i$ grafikach Kajetana Wincentego Kielisinskiego (1808-1849) [Sum. The Archaeological Themes in the Drawings And the Graphic Art of Kajetan Wincenty Kielisiński (1808-1849], Poznań. 
Fryś-Pietraszkowa E.

1994 Rozkwit i zmierzch ceramiki siwej [Zus. Blütezeit und Untergang der Graukeramik], (w:) Gancarstwo i kaflarstwo na ziemiach polskich od późnego średniowiecza do czasów wspótczesnych. Materialy z konferencji-Rzeszów, 2I-23 IX 1993 (red. A. Gruszczyńska, A. Targońska), Rzeszów, s. 15-19.

Gąsiorowski A.

1968 Urzędnicy wielkopolscy 1385-1500. Spisy [Zus. Das grosspolnische Beamtentum in den Jahren 1385-1500. Verzeichnisse], Poznań.

1970 Urzędnicy zarzqdu lokalnego w późnośredniowiecznej Wielkopolsce [Rés. Les fonctionnaires de l'administration lokale en Grande Pologne du haut Moyen-Age], Poznań.

G ło s e k M.

1998 Dwór murowany w Bqqkowej Górze [Zusammenfassung], Łódź.

Grygiel R., Jurek T.

1994 Doliwowie z Nowego Miasta nad Wartq, Dębna i Biechowa. Dzieje rezydencji i ich wtaścicieli [Sum. The Doliwa family of Nowe Miasto-on-Warta, Dębno and Biechowo. A history of the residences and of their owners], Lódź.

$\mathrm{HaleckiO}$.

1911-1913 Ród Lodziów w wiekach średnich, „Miesięcznik Heraldyczny”, t. IV, 1911, s. 113-117, 150-160, 185-189; t. V, 1912, s. 8-14, 47-54, 77-88, 107-115, 144-156, 179-190; t. VI, 1913, s. 8-17, 41-50, 72-77, 102-106.

Hilczerówna Z.

1967 Dorzecze gómej i środkowej Obry od VI do poczq̨tów XI wieku, Wrocław - Warszawa Kraków.

Jankowska D.

1985 Osadnictwo w Niecce Jezior Bnińskich w epoce kamienia. Mikroregion bniński [Zus. Das Siedlungswesen in der Mulde der Bnin-Seen in der Steinzeit], (w:) Materiaty do studiów nad osadnictwem bnińskim. Mikroregion bniński (red J. Żak i J. Fogel), Poznań, s. 21-34.

Jurek T.

1993 Kasztelan kaliski Andrzej z Bnina († 1367) - przodek Bninskich herbu Lodzia, „Genealogia. Studia i materiały historyczne", t. 3 , s. 39-43.

Kajzer L.

1990 Zamek w Raciqziku [Zus. Das Schloss in Raciążek in Kujawy], Łódź.

1991 W sprawie waloryzacji masowych zbiorów ceramiki późnośredniowiecznej i nowożytnej [Sum. On the evaluation of mass assemblages of late medieval and modern pottery], „Kwartalnik Historii Kultury Materialnej”, r. 39, nr 4, s. 468-483.

1993 Zamki $i$ spoleczeństwo. Przemiany architektury i budownictwa obronnego $w$ Polsce $w X-$ XVIII wieku [Zus. Burgen und Gesellschaft. Umwandlungen der Architektur und der Verteidigungsbauten in Polen 10.-18. Jarhundert], Łódź.

1994 „Glówne momenty” raz jeszcze. Uwagi o przemianach garncarstwa późnośredniowiecznego i nowożytnego w Polsce [Zus. „Hauptmomente” noch einmal. Bemerkungen zu den Veränderungen in der spätmittelalterlichen und neuzeitlichen Töpferei in Polen], (w:) Garncarstwo i kaflarstwo na ziemiach polskich od późnego średniowiecza do czasów wspótczesnych. Materialy z konferencji - Rzeszów, 21-23 IX 1993 (red. A. Gruszczyńska, A. Targońska), Rzeszów, s. 9-13.

1996 Wstep do archeologii historycznej $w$ Polsce [Sum. The introduction to the historical archaeology in Poland], Łódź.

Karłowska-K a mzowa A.

1969 Zamek kórnicki w średniowieczu i epoce nowożytnej, „Pamiętnik Biblioteki Kórnickiej”, t. 9-10, s. 5-38. 
Kirchhoff $\mathrm{K}$.

1994 Kafle naczyniowe i płytowe z okresu od XV do XVIII wieku z Zamku Kórnickiego, Poznań (maszynopis pracy magisterskiej w bibliotece Instytutu Prahistorii UAM w Poznaniu).

Kirschke B., Prinke A.

1995 Grodziska w województwie poznańskim. Katalog stanowisk archeologicznych [Summary], Poznań.

Kóčk a-K renz H.

1993 From the Research into Medieval Wooden Tower Houses on the Polish Territories, (in:) Study of Medieval Archaeology, Lund Studies in Medieval Archaeology, 13, Stockholm, s. 293-299.

Kodeks Dyplomatyczny Wielkopolski (KDW)

1908-1999 Kodeks Dyplomatyczny Wielkopolski: t. V (wyd. I. Zakrzewski, F. Piekosiński), Poznań 1908; t. VIII (wyd. A Gąsiorowski, T. Jasiński), Warszawa - Poznań 1989; t. XI (wyd.

A. Gąsiorowski, T. Jasiński, T. Jurek, I. Skierska), Poznań 1999.

Kościński B.

1995 Osada w Racocie (stanowiska 18 i 25), gmina Kościan, woj. leszczyńskie [Zus. Frühmittela]terliche Siedlung in Racot (Fst. 18 und 25), Gemeinde Kościan, Woiwodschaft Leszno], (w:) $Z$ badań nad osadnictwem wczesnośredniowiecznym Wielkopolski poludniowej (red. Z. Kurnatowska), Poznań, s. 83-258.

Kozierowski S.

1913-1915 Studia nad pierwotnym rozsiedleniem rycerstwa wielkopolskiego, III. Ród Wczeliczów, „Miesięcznik Heraldyczny”: t. VI, 1913; t. VII, 1914, s. 59-67, 103-113; t. VIII, 1915, s. $130-156$.

1916a Badania nazw topograficznych dzisiejszej archidiecezji poznańskiej (A-O), „Roczniki TPNP" 41, s. 1-577.

1916b Badania nazw topograficznych dzisiejszej archidiecezji poznanskiej (P-Ż), „Roczniki TPNP" 42, s. $1-505$.

1923 Studia nad pierwotnym rozsiedleniem rycerstwa wielkopolskiego, IX. Ród Doliwów, Poznań.

1934 Szematyzm historyczny ustrojów parafialnych dzisiejszej archidiecezji gnieźnieńskiej, Poznań.

1935 Szematyzm historyczny ustrojów parafialnych dzisiejszej archidiecezji poznańskiej, Poznań.

Krause E.

1976 Grodzisko stożkowate w Bninie koło Śremu [Zus. Turmhügel (Motte) in Bnin neben Śrem], (w:) Materialy do studiów nad osadnictwem bnińskim. Grodzisko stożkowate (red. J. Żak), Warszawa - Poznań, s. 3-115.

Kruppé J.

1961 Studia nad ceramikq XIV wieku ze Starego Miasta w Warszawie [Sum. Research work on XIVth century ceramics of the Old City of Warsaw], Wrocław - Warszawa - Kraków.

1981 Garncarstwo późnośredniowieczne w Polsce, cz. 1 i 2, Wrocław - Warszawa - Kraków Gdańsk - Łódź.

Liber beneficiorum

1950 Liber beneficiorum dioecesis posnaniensis anni 1510 (Księga uposażenia diecezji poznańskiej z roku 1510), [Summary], (red. J. Nowacki), Poznań.

Las zkiewicz A.

1997 Kafle i piece kaflowe z dworu na kopcu w Krajkowie pod Mosinq, woj. poznańskie [Sum. Tiles and tile stoves from the manor on the mound at Krajkowo near Mosina, Poznan province], Poznań.

Łosiński W., Rogosz R.

1986 Próba periodyzacji ceramiki wczesnośredniowiecznej ze Szczecina, (w:) Problemy chronologii ceramiki wczesnośredniowiecznej na Pomorzu Zachodnim, Warszawa, s. 51-61. 
Maik J.

1988 Wyroby wtókiennicze na Pomorzu z okresu rzymskiego i ze średniowiecza [Sum. The textiles of Pomerania in the Roman period and in the middle ages], Wroclaw - Warszawa Kraków - Gdańsk - Łódź.

1997 Sukiennictwo elblaskie w średniowieczu [Zus. Elbinger Wollweberei im Mittelalter], Łódż.

Marciniak A.

1991 Budownictwo obronne w "Liber beneficiorum" Jana Dlugosza a realia archeologiczne [Sum. Defensive buillding in Liber beneficiorum by Jan Długosz and archaeological realities], Folia Archaeologica 12, Łódź, s. 161-198.

Marciniak-Kajzer A., Nowakowski P.A.

1999 Ratownicze badania wykopaliskowe na stanowisku nr I w miejscowości Leszcz, gm. Dqbrówno, w woj. warnińsko-mazurskim [Sum. Rescue excavations at site 1 in Leszcz, Dabrówno commune, Warmia-Mazury (Ermeland-Mazuria) province], „Lódzkie Sprawozdania Archeologiczne", t. V, s. 257-265.

Mizerka J

1994 Renesansowe kafle piecowe z Gniezna (stan. 225), Poznań (maszynopis pracy magisterskiej w bibliotece Instytutu Prahistorii UAM w Poznaniu).

Munsell

1973 Munsell Soil Color Charts, Baltimore.

Niegoda J.

1999 Naczynia ceramiczne, (w:) Ze studiów nad życiem codziennym w średniowiecznym mieście. Parcele przy ulicy Więziennej 10-11 we Wroclawiu (red. C. Buśko i J. Piekalski), Wrocław, s. $157-182$.

Nowacki J.

1964 Dzieje archidiecezji poznańskiej, t. II. Archidiecezja poznańska w granicach historycznych $i$ jej ustrój [Sum. The historical boundaries and structure of the Poznań archidiocese], Poznań.

Nowaczyk B.

1985 Rozwój geomorfologiczny rynny glacjalnej Jezior Kórnicko-Zaniemyskich (Bninskich) w aspekcie osadniczym [Zus. Die Geomorphologische Entwicklung der Glazialen Rinne der KómikZaniemyśl-Seen (der Bnin-Seen) in einer Siedlungsblickrichtungl, (w:) Materiaty do studiów nad osadnictwem bnińskim. Mikroregion bniński (red. J. Żak i J. Fogel), Poznań, s. 7-19.

Pałubicka A.

1975 Grodzisko wklęsle w Bninie, pow. śremski [Zus. Niederungsburg in Bnin, Kreis Śrem], (w:) Materiaty do sfudiów nad osadnictwem bninskim. Grodzisko wklęste (red. J. Żak), Poznań.

Piekalski J.

1991 Wroctaw średniowieczny. Studium kompleksu osadniczego na Otbinie w VII-XIII w. [Sum. Miedieval Wrocław. Study of the settlement complex at Ołbin in the VII-XIII centuries], Wrocław.

Poliński D.

1996 Przemiany w wytwórczości garncarskiej na ziemi chetmińskiej u schytku wczesnego i na poczq̨iku późnego średniowiecza [Sum. Changes in pottery production in the Chełmno land at the end of the early middle ages at the beginning of the late middle ages], Torun.

2000 Niektóre zwiqzki późnośredniowiecznego garncarstwa ziemi chetmińskiej z obszarami Europy zachodniej [Sum. Some connections between late-medieval pottery production in the Chełmno land and Western Europe], „Archaeologia Historica Polona”, t. 8, s. 115-129.

Rzeźnik P.

1998 Przemiany wytwórczości garncarskiej średniowiecznego Wroctawia w czasie wielkiej reformy miejskiej, (w:) Kultura średniowiecznego Ślaska i Czech. „Rewolucja” XIII wieku (red. K. Wachowski), Wroclaw, s. 12I-153. 
Sikorski A.

1995 Ceramika naczyniowa z Łekna, stanowisko nr 3 (wykopy VIII i IX) [Sum. Pottery from Łekno, stand 3 (Excavation VIII and IX)], (w:) Studia i materiały do dziejów Pałuk (red. A. M. Wyrwa), t. 2, Poznań, s. 95-120.

1998 Wyniki analiz fragmentów tkanin odciśniętych na ceramice z osady wczesnośredniowiecznej w Nowej Wsi, s. 12 (43a), (w:) Archeologiczne badania ratownicze wzdtuż trasy gazociagu tranzytowego, t. 1, Ziemia Lubuska (red. R. Mazurowski), Poznań, s. 191-195.

2000 Odciski tkanin na renesansowym kafiu z Łekna [Sum. Cloth imprints on a renaissance stovetile from Łekno], „Archaeologia Historica Polona”, t. 8, s. 143-152.

Słownik historyczno-geograficzny pozn.

Stownik historyczno-geograficzny województwa poznańskiego w średniowieczu, część I: zeszyt 1 (A-B), 1982; zeszyt 2 (Ca-Dębowa Łęka), 1983; zeszyt 3 (Dębowa Łęka-Gorzyca), 1986; zeszyt 4 (Gorzyce-Hyze), 1987; część II: zeszyt 1 (Ihylowiecz-Kęszyca), 1998; zeszyt 2 (KęszycaKoszino), 1991; zeszyt 3 (Koszkowo-Kuczyna), 1991; zeszyt 4 (Kuczyna-Lwówek), 1992; część III: zeszyt 1 (L-Myszkowo), 1993; zeszyt 2 (Myszkowo-Oporowo), 1995; zeszyt 3 (Oporowo-Pniewo), 1997; zeszyt 4 (Pniewy-Q), 1999; część IV, zeszyt l (R), 2001.

Studia i materiały (SiM)

1950-1995 Studia i materiaty do osadnictwa Wielkopolski wczesnohistorycznej: Hensel W., t. 1, Poznań 1950; t. II, Poznań 1953; t. III, Warszawa 1959; Hensel W., Kurnatowska-Hilczer Z., t. IV, Wrocław - Warszawa - Kraków - Gdańsk 1972; t. V, Wrocław - Warszawa - Kraków - Gdańsk 1980; t. VI, Wrocław - Warszawa - Kraków - Gdańsk - Lódź 1987; Hensel W., Kurnatowska-Hilczer Z., Łosińska A., t. VII, Poznań - Toruń 1995.

Sulk ow s ka-T us z yń s k a K.

1997 Sredniowieczne naczynia ceramiczne z klasztoru norbertanek $w$ Strzelnie [Summary], Torun.

Szamałek K., Dudziak-Jankowiakowa J., Karolczak Z.

1979 Osadnictwo podgrodzia bnińskiego [Zus. Besiedlung der Vorburg in Bnin], (w:) Materiaty do studiów nad osadnictwem bnińskim. Podgrodzie (red. J. Żak), Poznań.

Sz weda A.

2001 Ród Grzymatów w Wielkopolsce, Toruń.

Urzędnicy

1985 Urzędnicy wielkopolscy XII-XV wieku. Spisy (opr. M. Bielińska, A. Gąsiorowski, J. Łojko, red. A. Gąsiorowski), Wrocław - Warszawa - Kraków - Gdańsk - Łódź.

Wielkopolskie roty

1960 Wielkopolskie roty sqdowe XIV-XV wieku (wyd, H. Kowalewicz, W. Kuraszkiewicz), t. II. Roty pyzdrskie, Warszawa - Poznań - Wrocław.

Wojciechowski A.

1999 Late Glacial and Holocene Lake - level Fluctuations on the Kórnik-Zaniemyśl Lake Area, Great Poland Lowland, „Quaternary Studies in Poland”, 16, s. 81-101.

\section{„NEUER” SPÄTMITTELALTERLICHER BURGHÜGEL IN DER NÄHE DER BNIŃSKIE-SEEN (BEAŻEJEWO, GEM. KÓRNIK, WOI. WIELKOPOLSKA, GROSSPOLEN)}

\section{Zusammenfassung}

Die für die Archäologen „neuentdeckte” historische Quelle (Codes Diplomaticus Maioris Poloniae, B. VIII.. Nr. 935, datiert in 9. März 1422) behandelt das spätmittelalterliche castrum in Błażejewo (Gem. Kórnik, Woi. Wielkopolska), das eher repariert oder ausgebaut als vom Eigentümer - Andrzej 
Błażejewski, der - wie es scheint - seinen Ursprung von Łodzia Bniński-Familie ableitete und in die Familie Grzymała einheiratete - erst errichtet wurde. Vielseitige genealogische und Eigentumsrundfragen (Kapitel 1) erlauben es, die hypothetische Anlage eines gewissen Wohnsitzes in Błażejewo schon in der 2. Hälfte des 14. Jh. der Familie Grzymała, vielleicht persönlich dem Mikołaj von Błażejewo zuzuschreiben. Das Funktionieren eines im oben erwähnten Dokument beschriebenen Objekts, das wahrscheinlich die zweite Phase des dortigen castrum - fortalicium ist, sollte sich in ziemlich engem Zeitintervall: Anfang des 15. Jh. (vor 1422) - Mitte des 15. Jh. (zwischen 1459/1464 und 1513) schließen.

Mit der Geschichte der befestigten Residenz in Błażejewo, die zuerst der Familie Grzymała und später der Familie Lodzia gehörte, steht im offenbaren Zusammenhang die Geschichte der dortigen Pfarrei und Kirche. Die aus einem Dorf bestehende Pfarrei in Błażejewo, die eine Holzkirche hatte, konnte schon in der 1. Hälfte des 14 . Jh. (nach J. Nowacki) erbaut werden. Ihre Funktionierung während des ganzen 15. Jh. ist zweifellos. Im Jahre 1513 wurde sie in die Präpositur Bnin inkorporiert (Kapitel 1).

Das für uns grundlegende Dokument aus dem Jahre 1422 informiert ziemlich ausführlich über manche Elemente der Residenz in Błażejewo. Dort ist die Rede von ,... allen entsprechenden Bauten am befestigten Ort (castri) und vor dem befestigten Ort (ante castrum) [...], nämlich von den Häusern, einem Turm mit kleinen Dächern, genannt Zinnen, einem Graben [mit ?] einem gedielten Weg (pons) ..." sowie von ,... einem Weg, der umgangssprachlich »ku walom « (nach den Wällen)" genannt war.

Eine Koinzidenz der historischen, archäologischen und geologischen Angaben, die sich auf das castrum in Błażejewo bezieht, haben die Geländeprospektionen, die früheren und die aus dem Jahre 2000, ermöglicht (Kapitel 2 und 3). Im Ergebnis dieser Untersuchungen wurde - als wahrscheinlichste die Lage des gesuchten Objekts - Fundstelle 4 in Błażejewo, auf der Halbinsel des Bnińskie Sees bestimmt, die sich topographisch in der Umgebung entschieden auszeichnet (Kapitel I, 2). Obwohl es nicht gelang, auf dieser Fundstelle Bauüberreste zu finden, haben der große, natürliche Verteidigungswert dieser Stelle und die in örtlicher, mündlicher Tradition eindeutig bewahrte Lokalisierung der alten Kirche in der Nähe der erwähnten Halbinsel, also vermutlich unweit der machthaberischen Residenz, Aufmerksamkeit gezogen.

Das infolge einer archäologischen Landesaufnahme erhaltene keramische Material (Gefäßscherben), in ausreichend großer Repräsentativprobe, bestand aus urgeschichtlichen, frühmittelalterlichen (Phasen D-E und F), spätmittelalterlichen (14.-15./16. Jh.), neuzeitlichen (16.-18. Jh.) und uns zeitgenössischen Exemplaren (Tabelle 1). Zu betonen ist die Tatsache, daß in der analysierten Sammlung der Anteil der spätmittelalterlichen Keramik am größten war $(45,1 \%)$.

Das untersuchte geologische Profil der Fundstelle 4 (Kapitel 3, Abb. I B und 4) beweist, daß der mittlere, sandige und immer trockene Teil der Halbinsel über die Umgebung erhoben war. Die am Ansatz der Halbinsel herausragende Vertiefung erwies sich als eine natürliche, in genetischer Hinsicht spätpleistozäne Form, die mit sehr dicken, in Bedingungen jahrhundertelanger Versenkung entstandenen Torfablagerungen gefültt ist. Die erwähnte, mit Wasser und Torf gefüllte Vertiefung trennte die Halbinsel vom „Festland" und funktionierte wahrscheinlich als ein Festungsgraben.

Aus Mangel an entsprechenden Angaben ist es schwierig zu versuchen, den vermutlichen Turmhügel in Błażejewo näher zu klassifizieren. Sogar das Bestehen eines Erddamms - „Erdhügels” - bleibt in der Vermutungssphäre. Aus der schriftlichen Quelle wissen wir dagegen, daß sich im Bereich des „,befestigten Ortes" nicht nur ein sondern mehrere Holzgebäude befanden. Das wichtigste davon war ein Wohnturm, der wahrscheinlich - wie es die Analogien vorsagen - aus mehreren Etagen gebaut und mit Zinnen beendet war. Vorsichtig stellen wir die Hypothese auf, daß ein anderes Bebauungselement das „Vorwerk” am nordôstlich des Turms gelegenen Plateau war (Kapitel 3, Abb. 1 B). Die Form der Befestigungen selbst ist diskutabel. Aus dem topographischen Kontext scheint es zu erfolgen, daß sie keine geschlossene Ringform haben mußten, sondern eine Abschnittsform, die den Hof von westlicher Seite, 
also von der Seite des „Festlandes” schützte. In diesem zweiten, mehr wahrscheinlichen Falle, war das Schutzelement der oben besprochene „Festungsgraben”. AuBerhalb der befestigten Schutzzone (ante castrum) gab es gewisse Gebäude, vielleicht mit Wirtschaftscharakter. Vom Dorf „bis zu den Wällen” führte ein gedielter Weg, der über den „Festungsgraben” auf einer Brücke verlief.

Die Relationen des Objekts aus Błażejewo zu zwei anderen, ähnlichen Turmhügeln auf dem Gebiet der Mulde von Bnińskie Seen: in Bnin (Gem. Kórnik, Fst. 1) und in Łękno (Gem. Zaniemyśl, Fst. 2) können wir nicht bestimmen.

Bezüglich der seit einigen zehn Jahren geführten Diskussion über die Nutzung der Mulde von Bnińskie Seen als eine kombinierte - natürliche und befestigte - Verteidigungslinie beim Angriff der Kreuzritter auf Großpolen um die Wende Juli und August 1331, den Jan Długosz beschrieben hatte, können wir feststellen, daß die Turmhügel in Bnin und Łękno schon damals Ruinen waren. Sie konnten also keine aktiven Widerstandspunkte sein (ähnlich war es bei den Ringburgen in Bnin und Kępa Wielka sowie bei der vermutlichen Burg auf der Edouards-lnsel in Zaniemyśl). Das castrum der GrzymałaFamilie in Błażejewo gab es noch nicht. 